\title{
Comparative mineralogical and fluid inclusion study of the Hnúšs'a- Mútnik talc-magnesite and Miková-Jedl'ovec magnesite deposit (Western Carpathians, Slovakia)
}

\author{
PETER KODĚRA $^{1}$; MARTIN RADVANEC ${ }^{2}$ \\ ${ }^{1}$ Geological Survey of Slovak Republic, Mlynská dolina 1, 81704 Bratislava, Slovakia \\ kodera@gssr.sk \\ ${ }^{2}$ Geological Survey of Slovak Republic, Markušovská cesta 1, 05201 Spišská Nová Ves, Slovakia \\ radvanec@gsrcsnv.sk
}

(Received December 2002 Accepted December 2002)

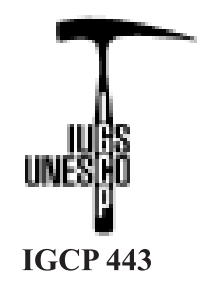

\begin{abstract}
Two type localities, located in two different geological and metamorphic units, have been studied. The Hnúšt' a-Mútnik deposit is located in amphibolite facies rock sequences of the Veporic unit, while the Miková-Jedl'ovec deposit (a part of the Dúbrava massive) is located in greenschists facies sequences of the Gemeric unit. On both localities successive crystallisation occurred during three stages of replacement. The first two belong to an older metamorphic process M1, the third corresponds to a younger M2 metamorphic process. During the first stage dolomite1 and calcite 1 has formed on the expense of protolithic limestone. The second (major) stage is characterized by crystallization of magnesite. The third stage is represented by dolomite2, talc, chlorite, pyrite. At Hnúšt'a-Mútnik this stage is much better developed and is further accompanied by tremolite, phlogopite, clinozoisite, zoisite. Based on the carbonate geothermometry at Hnúšt’a-Mútnik the first stage occurred at $280-400^{\circ} \mathrm{C}$ and the third stage at $490-540^{\circ} \mathrm{C}$; at Miková-Jedl'ovec the first stage crystallized at $370-420^{\circ} \mathrm{C}$.

Fluid inclusion study in magnesite showed the presence of primary brine inclusions, with high concentrations of salts other than $\mathrm{NaCl}$, probably highly evolved evaporated marine waters. Brines from Miková-Jedl'ovec are slightly less saline (23-24 wt\% $\mathrm{NaCl}$ eq.) and homogenised at lower temperatures $\left(195-248^{\circ} \mathrm{C}\right.$ ) than the brines from Hnúšt' a-Mútnik (29-32 wt\% $\mathrm{NaCl}$ eq., 299 $348^{\circ} \mathrm{C}$ ). Brines are accompanied by $\mathrm{CO}_{2}$-rich inclusions with nearly identical parameters at both deposits (1-8 wt $\% \mathrm{NaCl}$ eq., $\mathrm{CO}_{2}$ density 0.53 to $0.69 \mathrm{~g} . \mathrm{cm}^{-3}$, Th 307 to $\left.336^{\circ} \mathrm{C}\right) . \mathrm{CO}_{2}$ fluids probably result from dissolution of carbonates and are coeval or younger than brines. At MikováJedl'ovec also low salinity aqueous fluid inclusions have been identified (3-8 wt $\% \mathrm{NaCl}$ eq., Th $132-249^{\circ} \mathrm{C}$ ), corresponding to the stage 3 . Microthermometric data have been also used to determine pressure and temperature limits related to the second and partially to the third stage of replacement.
\end{abstract}

Key-words: magnesite, talc, dolomite, fluid inclusion, geothermometry, P-T conditions, Gemericum, Veporicum, Western Carpathians.

\section{Introduction}

Western Carpathians host numerous magnesite and talc-magnesite mineralizations, some of them of a significant economic value. During the last decades the problem of the genesis of this type of deposits has been investigated and discussed much, however it still far from clear, especially concerning the PT conditions and timing of the mineralizing events.
This study using new mineralogical, petrological and fluid inclusion data brings a new insight into the problem. Two type localities, located in two different geological and metamorphic units, have been selected for this comparative research: the Miková-Jedl'ovec magnesite occurring in the Gemeric unit and Hnúšt' aMútnik talc-magnesite deposits present in the Veporic unit (Fig. 1). 


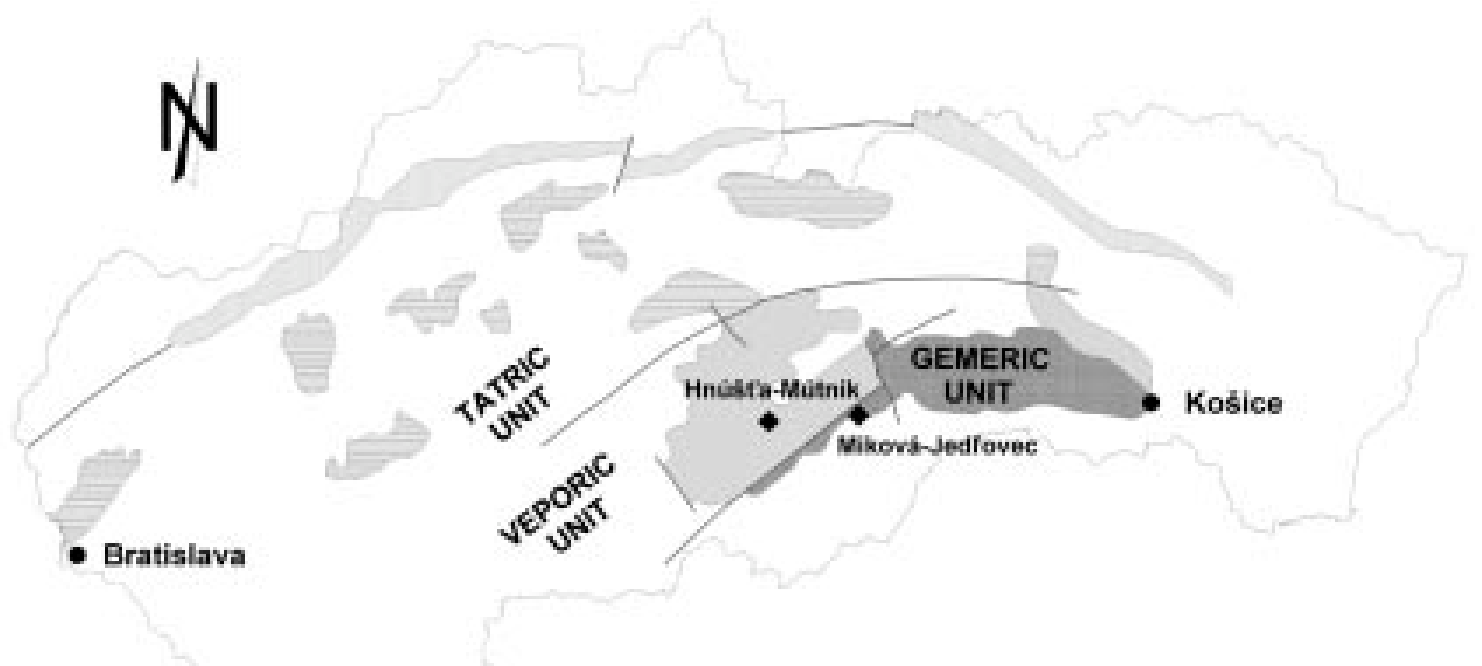

Fig. 1. Position of the studied deposits among the main Alpine tectonic unit of the Western Carpathians in Slovakia. Miková-Jedl'ovec magnesite deposit in the Gemeric unit consists mostly of greenschist facies. Hnúšt'a-Mútnik talc-magnesite-dolomite deposit in the Veporic unit is built up mainly by rocks of amphibolite facies. The Veporic unit borders in the north with the Tatric unit, consisting mainly of crystalline complexes.

\section{Geological setting}

Hnúšt'a-Mútnik talc-magnesite deposit

The Hnúšt'a-Mútnik talc-magnesite deposit (Fig.1) is located in chlorite schists of the Veporic unit with intercalations of amphibolites (Grecula et al., 2000). Talc is accompanied by magnesite bearing dolomitic intercalations. Carbonatic body is strongly tectonized and is accompanied by a strong mylonitization at margins with chlorite schists and amphibolite host rocks. Amphibolites are indexed by the mineral assemblage as follows: actinolite - paragonite + almandine + biotite + oligoclase-albite + epidote + quartz.

The deposit consists of several magnesite-talc lenses and individual bodies of clinochlore-leuchtenbergitetalc schists but only three discontinuous magnesite-talc lenses are of economic value in terms of talc. The lenses are irregular and very quickly fade out. Only one of the lenses, with the thickness above $20 \mathrm{~m}$, has a more continuous course with E-W orientation, dipping to $\mathrm{E}$. However, the whole sequence is more than $100 \mathrm{~m}$ thick, dipping $45^{\circ}$ to $S$ (Suchár in Grecula et al., 2000). The lenses locally include calcite, pyrite, chalcopyrite, fluorite, pyrrhotite, tetraedrite, sphalerite, cobaltite, arsenopyrite, magnetite, bornite, chalcosine, gold and native $\mathrm{Bi}$.

\section{Miková and Jedl'ovec magnesite deposits (Dúbrava} Massive)

The designation "Dúbrava massive" covers three more or less separated magnesite deposits Dúbrava, Miková and Jedl'ovec. This large and tectonically separated $\mathrm{Mg}$-carbonate body is located $3.5 \mathrm{~km}$ to $\mathrm{NE}$ of Jelšava town, located in black schist. It has directional length of 4,500 m, NE-SW orientation and dips 55-60 to SE. The maximum thickness is $600 \mathrm{~m}$ (Abonyi \& Abonyiová, 1981; Grecula et al. 1995 and 2000).

The Dúbrava magnesite body is located in the western part of the massive and has an average thickness of 70-80 m. The magnesite body was proved in the inclined length of $1,500 \mathrm{~m}$ and is usually assembled in the lower part of the carbonate body. In the middle part of the massive (Miková) several magnesite bodies are present, reaching a thickness of 100-180 m. This deposit was explored over a length of $1,300 \mathrm{~m}$. The eastern part (Jedl'ovec) consists of small magnesite bodies of variable thickness of 5-50 m. It was explored in a distance of approximately 1,300 $\mathrm{m}$ along its dip. 
In the Dúbrava part of the magnesite deposit, the successive replacement of the Upper Carboniferous limestone to dolomite and magnesite was studied using the relationship between minerals, inclusion fluid chemistry and petrology (Pašienka and Soták in Grecula et al., 2000; Radvanec and Prochaska, 2001). The host rock, black schist, contains the mineral assemblage: graphite(?)-organic matter, quartz, chlorite 1 (ripidolite), muscovite-illite, Fe-chloritoid, pyrite, kaolinite, rutile, monazite, zircon, xenotime and sphalerite. The Mgcarbonate body is predominantly formed by magnesite and first generation of dolomite, small amounts of dolomite 2, two generations of calcite, Fe-magnesite, talc, chlorite 2 (clinochlore), graphite(?)-organic matter, apatite, quartz and pyrite. Radvanec and Prochaska (2001) distinguished two progressive $(a, b)$ stages of mineralisation, followed by a separated stage (c).

a) The first stage of replacement included the reequilibration of relicts of sedimentary calcite 1 and the formation of dolomite $1+$ calcite 2 in the temperature range $370-400^{\circ} \mathrm{C}$. The temperature was calculated using the carbonate geothermometry (Powell et al., 1984).

b) The second stage represents the major stage of successive replacement with the formation of magnesite with a reduced amount of dolomite 1 related to the beginning of a retrograde metamorphism.

c) During the third stage a younger mineral assemblage has been formed: dolomite $2+$ talc + chlorite + quartz $+\mathrm{Fe}$-magnesite. The assemblage occurs in tiny veinlets, and vugs, crosscutting the magnesite body. This stage represents a time-separated metamorphic event related to a different source of fluids.

The successive replacement corresponds to the metamorphism in the greenschist facies, forming chloritoid and chlorite 1 in the host black schists.

\section{Previous fluid inclusion data}

First data on fluid inclusions hosted in minerals from magnesite deposits in Slovakia were published by Eliáš (1974, 1979). However, these data were limited to the recognition of high density $\mathrm{CO}_{2}$-bearing inclusions and acoustically registered decrepitation of inclusions in magnesite. Systematic study of fluid inclusions that allows more precise PTX interpretations started just two years ago.

Radvanec and Prochaska (2001) presented data on chemical composition of fluid inclusions in Dúbrava magnesite deposit ( $\mathrm{Li}, \mathrm{Na}, \mathrm{K}, \mathrm{Mg}, \mathrm{Ca}, \mathrm{F}, \mathrm{Cl}, \mathrm{Br}, \mathrm{SO}_{4}$ ), determined by ion chromatography from leaching solutions. Very low $\mathrm{Cl} / \mathrm{Br}$ - and $\mathrm{Na} / \mathrm{Br}$ - ratios of the inclusion fluids from magnesite as well as early dolomite plot at the end of the evaporation trend. This clearly documents the presence of highly evolved (halite fractionated) seawater to be the mineralizing fluid for the magnesite mineralisation. On the opposite, younger dolomite 2 showed different composition that was close to surface waters (high $\mathrm{Cl} / \mathrm{Br}-, \mathrm{Na} / \mathrm{Br}$ - ratios), possibly seawater. These fluids are assumed to be related to late stage, secondary, "dolomitization" (Radvanec and Prochaska, 2001).

Results on microthermometry of fluid inclusions in some other magnesite deposits located in the Northern Gemericum unit (Burda and Ploské) were recently published by Huraiová et al. (2002). In carbonates they recognised heterogeneously trapped $\mathrm{CO}_{2}$-rich and waterrich inclusions that were used to calculate conditions of origin. Metasomatic dolomite and magnesite from Burda crystallised from fluids with salinity 0.2 to 7.9 wt $\% \mathrm{NaCl}$ eq. at $232-242^{\circ} \mathrm{C}$ and $49-51 \mathrm{MPa}$, corresponding to $1.8-1.9 \mathrm{~km}$ of depth. Fluids in magnesite at Ploské had salinities 1.7 to $7.9 \mathrm{wt} \% \mathrm{NaCl}$ eq. Homogenisation temperatures values (Th) from both deposits were grouped between $100-130^{\circ} \mathrm{C}$ with trend of increasing salinity with increasing $\mathrm{Th}$.

\section{Sampling and analytical methods}

The research has been carried out on representative sample suites well constrained in terms of their field location and geological setting. Identical samples were used for the mineralogical, petrological and fluid inclusion study. Different types of carbonates and talc were collected from both localities:

- coarse-grained sparry magnesite, representing typical "Veitsch type" magnesite (Prochaska, 2000) usually with pinolitic structures,

- fine-grained dolomite (Dol1) usually occurring as "alteration haloes" around or inside the magnesite bodies, 
- late stage dolomite (Dol2), occurring in veins, fissures and vugs cutting the magnesite and accompanied by talc.

The samples have been studied by optical methods from polished thin sections. The chemical composition of the optically distinguished minerals was determined by Cameca SX-100 electron microprobe with the WDS and EDS analytical methods and using the mineral standards. On carbonates the data acquiring was performed for 3050 seconds, measuring contents of $\mathrm{Mg}, \mathrm{Fe}, \mathrm{Ca}, \mathrm{Mn}$ at standard analytical conditions (Table 2). Silicates were measured at standard analytical conditions (Table 3).

Thermometric behaviour of fluid inclusions was studied using doubly polished wafers ( 200mm thick) with a Linkam heating-freezing stage THMSG-600. The precision and accuracy of the microthermometric measurements, based on standard calibration procedures, is estimated at $\pm 0.2^{\circ} \mathrm{C}$ for temperatures below $-50^{\circ} \mathrm{C}$ and at $\pm 3^{\circ} \mathrm{C}$ for temperatures near $350^{\circ} \mathrm{C}$. Salinities estimates were determined from the last melting temperatures of ice (Bodnar, 1993), clathrate (Darling, 1991), hydrohalite and halite (Sterner et al., 1988). Densities and isochores for $\mathrm{H}_{2} \mathrm{O}$-rich inclusions were calculated using the equations of state of Zhang and Frantz (1987). Density of carbonic phase in $\mathrm{CO}_{2}-$ rich inclusions was calculated using data of Angus et al. (1976) from the regression of Parry (1986). Bulk density, bulk composition and isochores for $\mathrm{CO}_{2}$-rich inclusions have been calculated using the FLINCOR program (Brown, 1989), applying the equation of state Bowers \& Helgeson (1983) and visual estimates of phase proportions at temperature of partial homogenization of the $\mathrm{CO}_{2}$-rich phase.

\section{Mineral assemblages and petrology}

On both localities the Mg carbonate body is mostly formed by magnesite and the first generation of dolomite (Dol1) \pm calcite (Cal1), crystallised predominantly during an older metamorphic event, further referred as $M 1$ process. The second generations of dolomite (Dol2) and calcite (Cal2), Fe-magnesite, talc, chlorite (Chl2) and some other minerals formed during a different, apparently younger metamorphic event, further referred as M2 process (Table 1). On Hnúšt'a-Mútnik locality the products of the M2 process had heavily overprinted the magnesite-dolomite body forming a talc deposit (Table 1).

Table 1: Mineral assemblages of Mg carbonate bodies from the Miková-Jedl'ovec (Dúbrava massive) and the Hnúšt'a-Mútnik deposits.

\begin{tabular}{|c|c|c|c|c|}
\hline \multicolumn{2}{|c|}{ Mineral } & Miková-Jedl'ovec & Hnúšst'a-Mútnik & Metamorphic event \\
\hline Magnesite & Mgs & - & - & M1 \\
\hline Dolomite & Dol & 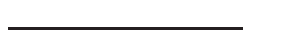 & & M1,M2 \\
\hline Calcite & $\mathrm{Cal}$ & & & M1,M2 \\
\hline Apatite & Ap & & $+\mathrm{REE} ;+\mathrm{Y} \ldots$ & M1 \\
\hline Rutile & $\mathrm{Rt}$ & $\ldots$. & (n) & M1 \\
\hline Quartz & Qtz & $\ldots$ & ..... & M1, M2 \\
\hline Monazite & Mo & (2) & & ? \\
\hline Zircon & $\mathrm{Zr}$ & $\ldots$ & & ? \\
\hline Xenotime & $\mathrm{Xe}$ & $\ldots$ & & ? \\
\hline Tremolite & $\operatorname{Tr}$ & & & M2-prograde \\
\hline Phlogopite & $\mathrm{Phl}$ & & & M2-prograde \\
\hline Clinozoisite & Czo & & & M2-prograde \\
\hline Zoisite & Zo & & & M2-prograde \\
\hline Talc & Tlc & & & M2-retrograde \\
\hline Chlorite & $\mathrm{Chl}$ & - & & M2-retrograde \\
\hline Phengite & Ms & & & M2-retrograde \\
\hline Illite & Ill & & & M2-retrograde \\
\hline Kaolinite & Kln & (............. & & M2-retrograde \\
\hline Pyrite & Py & & & M2 \\
\hline Sphalerite & $\mathrm{Sp}$ & & & M2 \\
\hline Goethite & Goe & & & M2 \\
\hline Titanite & $\operatorname{Ttn}$ & & & M2 \\
\hline
\end{tabular}

Explanations: 
KODİ RA, P.; RADVANEC, M. Comparative mineralogical and fluid inclusion study of the Hnúšt'a-Mútnik talc-magnesite and Miková-Jedl'ovec magnesite deposit (Western Carpathians, Slovakia)

Mineral assemblage formed during M1 process

At the Hnúšt'a-Mútnik and Miková-Jedl'ovec deposits similar mineral relationships of carbonates, corresponding to the older M1 metamorphic event, could be distinguished. During the M1 event a dominant amount of dolomite $1+$ calcite $1+$ magnesite was formed within a successive replacement of the former rock-forming calcite (Table 1 ).

In Dúbrava deposit the former calcite is a relict of the Upper Carboniferous shelf-limestone (Radvanec and Prochaska, 2001). In most parts, the dolomite 1 (Dol1) replaced sedimentary calcite, generating irregular rim at the boundary between relicts and the first generation of dolomite 1. Relicts of the protolithic limestone have been distinguished by the back-scattered electron images (BEI) in a limited set of samples. Most of the samples came from margins of the Dúbrava magnesite deposit and from its contacts with black shales (Radvanec and Prochaska, 2001). In the Veporic unit, even near the Hnúšt'a-Mútnik deposit, several localities of marbles are well known (Bezák V. ed., 1999). Consequently, this limestone is considered as the source carbonate, replaced by an $\mathrm{Mg}\left( \pm \mathrm{CO}_{2}\right)$-rich fluid to dolomite and magnesite.
The same is supposed to have occurred at the Dúbrava magnesite deposit. However, in samples from the Hnúšt'a-Mútnik and Miková-Jedl'ovec deposits the relicts of the primary sedimentary calcite do not occur.

Carbonates from the Hnúšt'a-Mútnik and MikováJedl'ovec deposits showed similar paragenetic relationships. The calcite $1\left(\mathrm{MgCO}_{3}\right.$ content 2.6 and 5.44 $\%$ in Hnúšt'a-Mútnik and $2.3 \%$ in Miková-Jedl'ovec) is disseminated in the form of small irregular to rounded grains in dolomite 1 as well as in magnesite (Table 2). Alike at the Dúbrava deposit, the spots of calcite (Cal1) in the matrix of dolomite (Dol1) are interpreted as an exsolution product (re-equilibration) of the former calcite by the $\mathrm{Mg} \pm \mathrm{CO}_{2}$-rich fluid during the first stage of replacement (Radvanec and Prochaska, 2001).

The second (major) stage of replacement is characterized by crystallization of major amount of magnesite with inclusions of dolomite 1 in the host magnesite (Figs. 2 and 4). Irregular to tabular inclusions of older dolomite 1 are frequently enclosed in the matrix inside the dominant, chemically homogeneous magnesite (Table 2). In this case the occurrence of the dolomite 1 inclusions is interpreted as a relict of the first stage of successive replacement.

Table 2: Representative analytical data of carbonates.

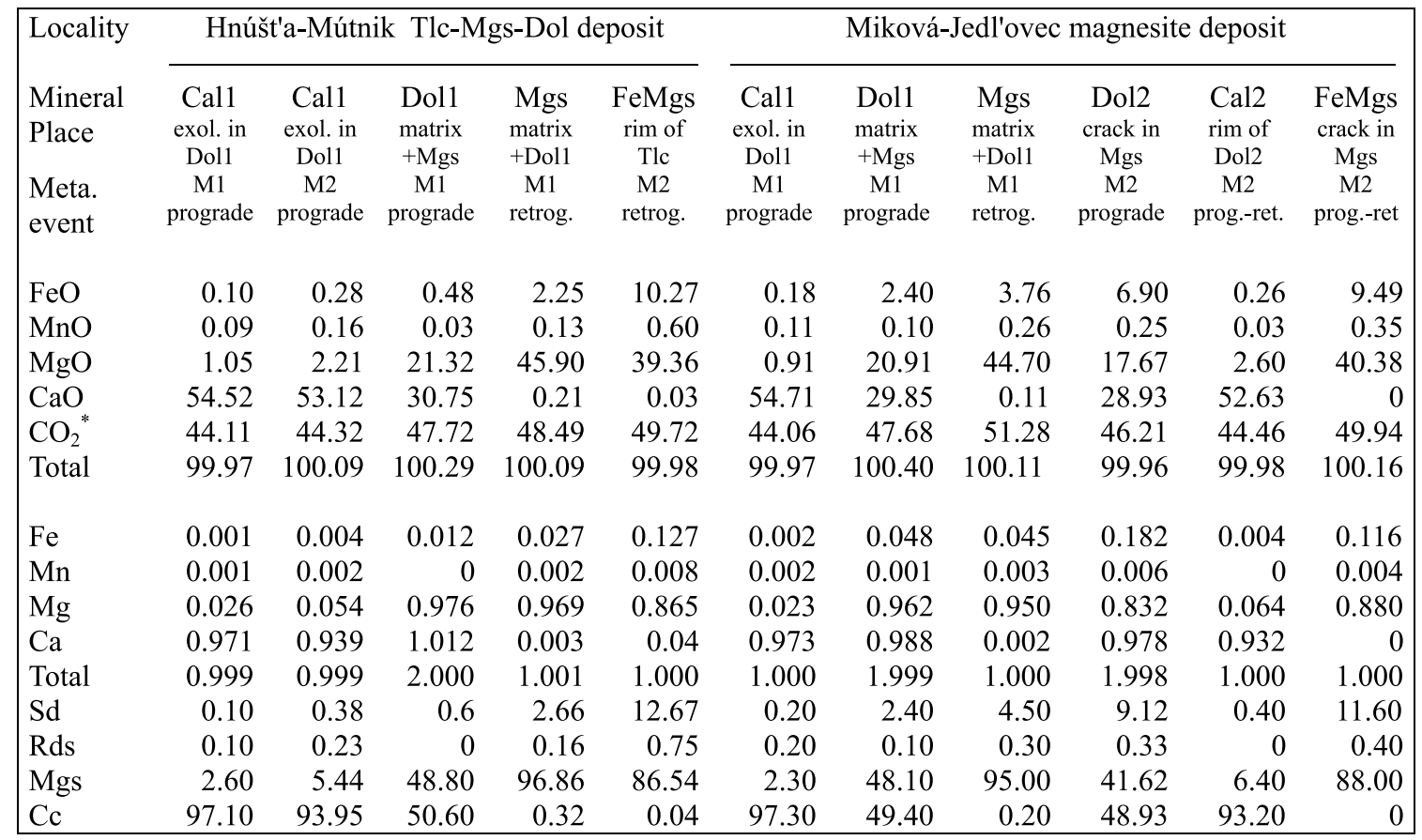

$\mathrm{CO}_{2} *$ is calculated from stoichiometry 


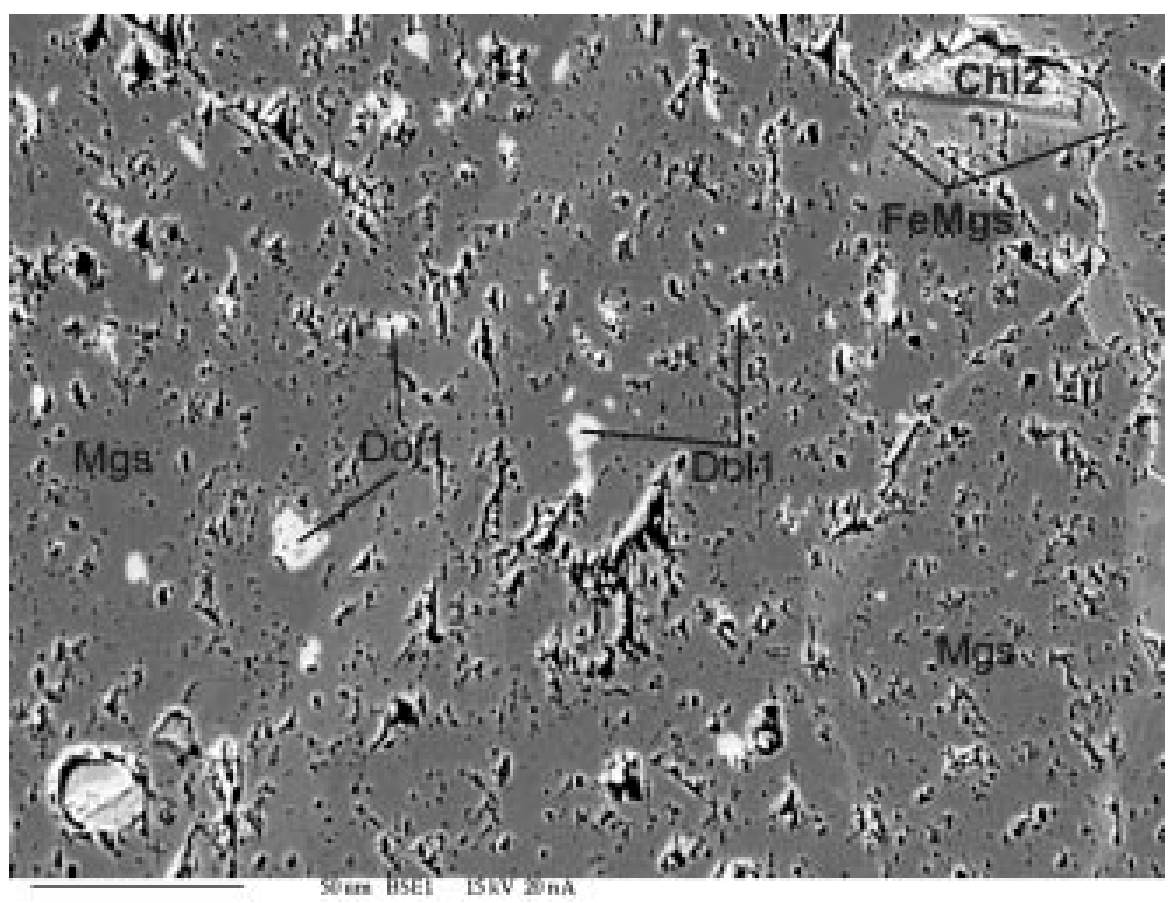

Fig. 2. Host-magnesite (Mgs) and irregular to rounded inclusions of dolomite 1 (Dol1) formed during the M1 metamorphic event. Chlorite 2 belongs to the younger mineral assemblage formed during the retrograde part of the metamorphic event M2. Locality Hnúšt'a-Mútnik. Back-scattered electron images (BEI). Chemical analyses are presented in Tables 2 and 3.

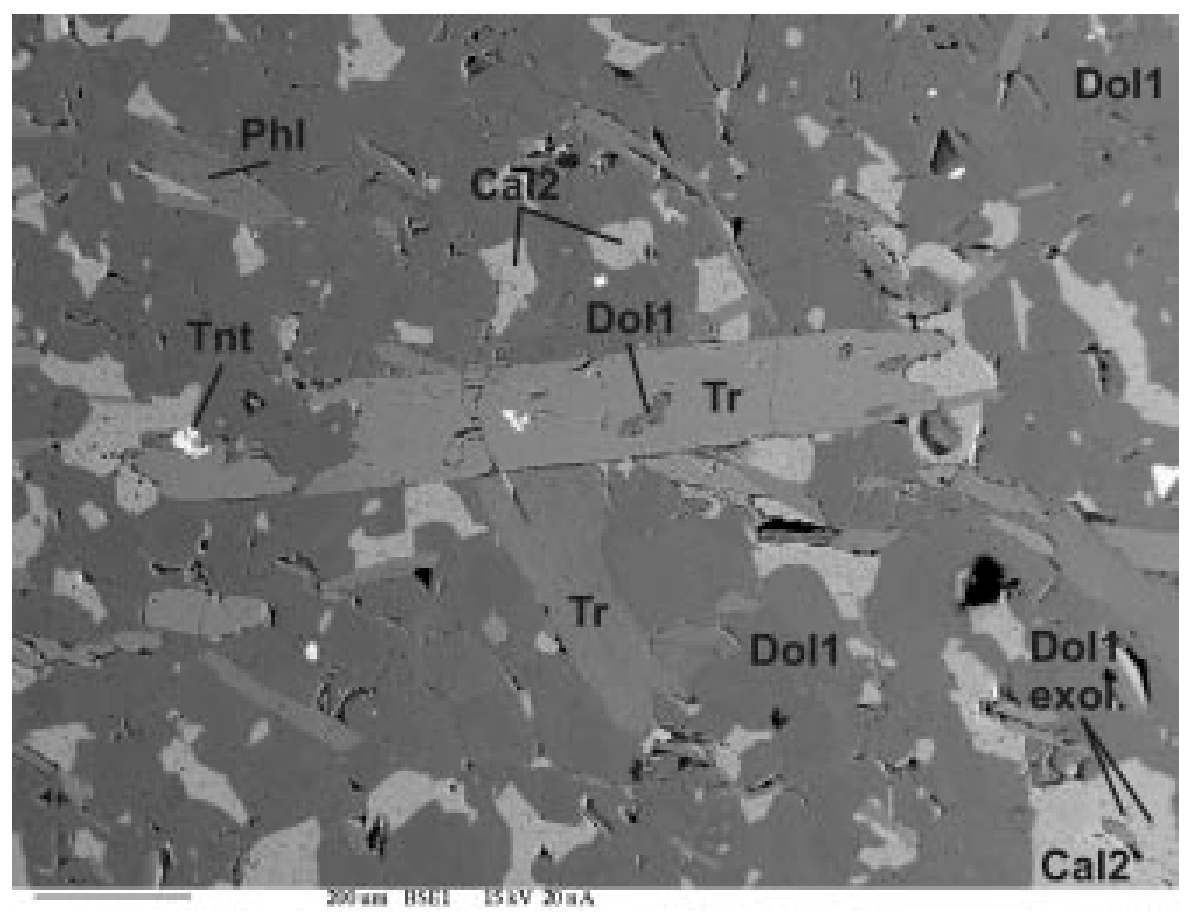

Fig. 3. Mineral assemblage of tremolite (Tr), phlogopite (Phl), calcite (Cal) and titanite (Tnt) formed during prograde part of the M2 event metamorphism. Calcite is always included in dolomite 2 (Dol2) that represents a chemical mixture of dolomite and calcite. Dolomite 1 (Dol1) is the host matrix mineral formed during the M1 process. Locality Hnúšt'a-Mútnik. Back-scattered electron images (BEI). Analyses are presented in Tables 2 and 3. 


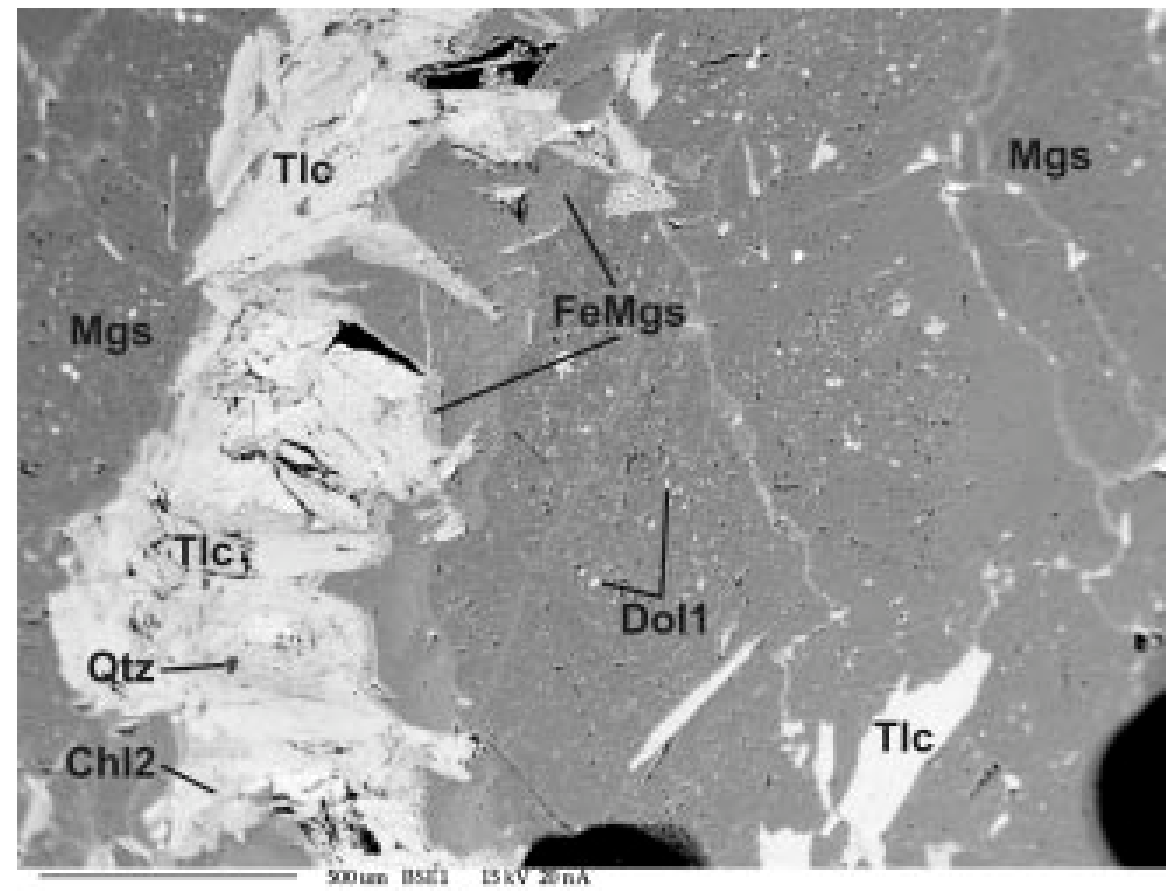

Fig. 4. Relationship between the host magnesite $(\mathrm{Mgs})$, including irregular and rounded inclusions of dolomite Dol1 and younger talc (Tlc) + quartz (Qtz) + chlorite $2(\mathrm{Chl} 2)+\mathrm{Fe}-$ magnesite (FeMgs), filling cracks in the matrix. The rim of cracks is represented by $\mathrm{Fe}-$ magnesite (FeMgs). Mineral assemblage Tlc+Qtz+Chl2+FeMgs was formed during the M2 process, while Mgs+Dol1 was formed during the M1 process. Locality Hnúšt'a-Mútnik. Back-scattered electron images (BEI). Analyses are presented in Tables 2 and 3.

The temperature of replacement was calculated using the carbonate geothermometry of Powell et al. (1994), based on their chemical composition. $X_{\mathrm{Fe}}=\mathrm{Fe} /$ $(\mathrm{Fe}+\mathrm{Mg}+\mathrm{Ca}+\mathrm{Mn})$ in dolomite 1 versus $\mathrm{X}_{\mathrm{Mg}}=\mathrm{Mg} /$ $(\mathrm{Fe}+\mathrm{Mg}+\mathrm{Ca}+\mathrm{Mn})$ in calcite 1 results in the temperature range $280^{\circ}$ to $400{ }^{\circ} \mathrm{C}$ for Hnúšt'a-Mútnik deposit and $370^{\circ}$ to $420^{\circ} \mathrm{C}$ for Miková-Jedl'ovec deposit respectively (Fig. 6). These temperature ranges had controlled the first stage of successive replacement with the formation of Cal1 + Dol1 \pm Mgs mineral assemblage, representing the temperature peak of the M1 process (Fig. 6). The main amount of the magnesite crystallised after the peak of M1 metamorphism.

\section{Mineral assemblage formed during M2 process}

In both deposits the main mineral assemblage representing the $\mathrm{M} 2$ process consists of dolomite $2+$ talc + chlorite $2+$ quartz + Fe-magnesite (Figs. 4 and 5,
Table 1). The M2 mineral assemblage is a result of the third stage of replacement producing idiomorphic or hypidiomorphic dolomite 2 , usually enclosing small and irregular grains of older magnesite.

The dolomite 2 also occurs in tiny veins, tenths of centimetres thick, and in vugs, crosscutting the magnesite structures. Dolomite 2 with inclusions of magnesite is well recognized in the youngest talc (Fig. 5 ). Inside the magnesite bodies, the dolomite $2+$ chlorite 2 (sheridanite-clinochlore-penninite) \pm pyrite fills cracks and small faults (Fig. 4). In the Hnúšt'a-Mútnik deposit the chlorite $2 \mathrm{Si}$ content ranged from 5.5 to 6.85 and $\mathrm{Mg} /\left(\mathrm{Mg}+\mathrm{Fe}^{2+}\right)$ content from 0.91 to 0.97 ; chlorite from Miková-Jedl'ovec had Si content 5.5 to 5.85 and $\mathrm{Mg}$ / $\left(\mathrm{Mg}+\mathrm{Fe}^{2+}\right)$ content 0.88 to 0.96 (Table 3). In the MikováJedl'ovec magnesite body the dolomite 2 is rimmed by calcite 2 with goethite inclusions. The dolomite 2 is accompanied by illite + muscovite + kaolinite inclusions (Figs. 5 and 8, Table 2 and 3). 


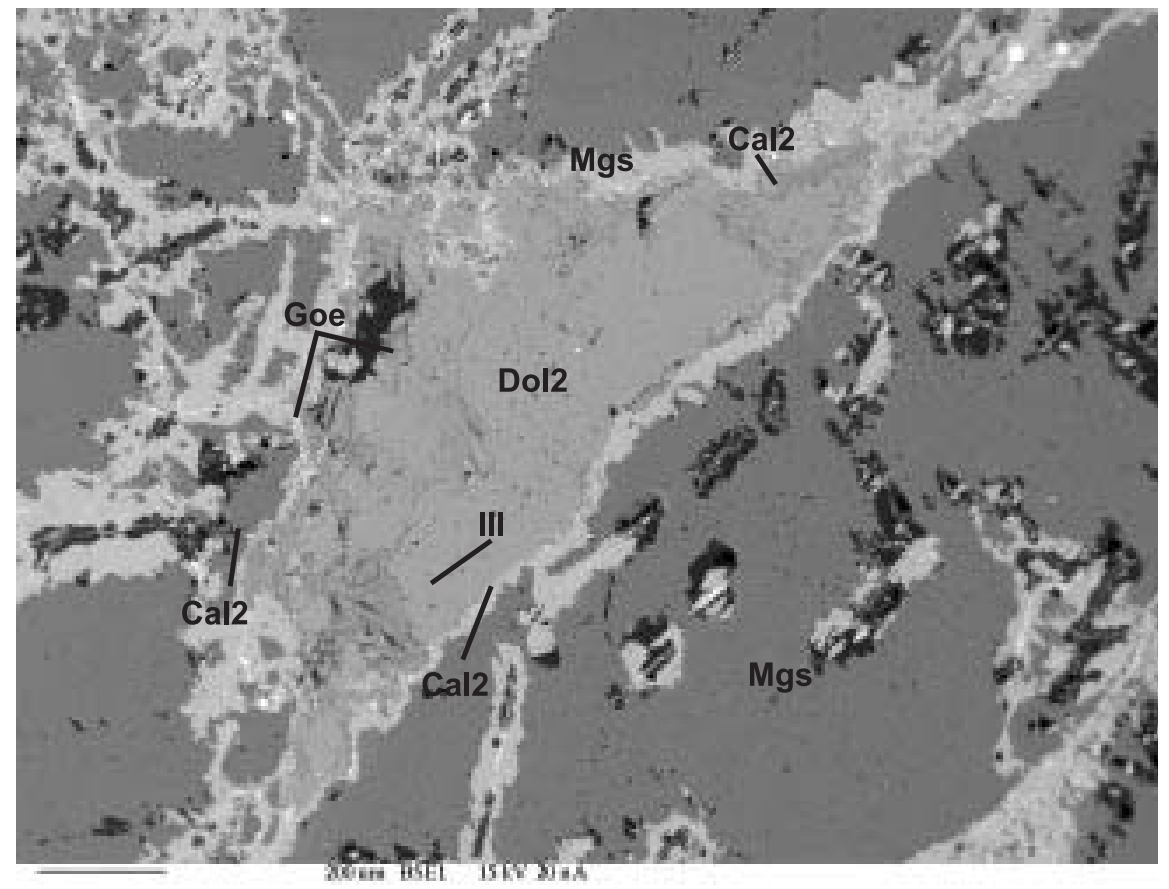

Fig. 5. Relationship between host magnesite (Mgs), younger dolomite (Dol2) and illite (Ill), present in cracks. The rim of Dol2 is replaced by calcite 2 (Cal2) and by goethite (Goe). Mineral assemblage Dol2+Ill+Cal2+Goe belongs to the M2 process. Locality MikováJedl'ovec. Back-scattered electron images (BEI). Analyses are present in Tabs. 2 and 3.

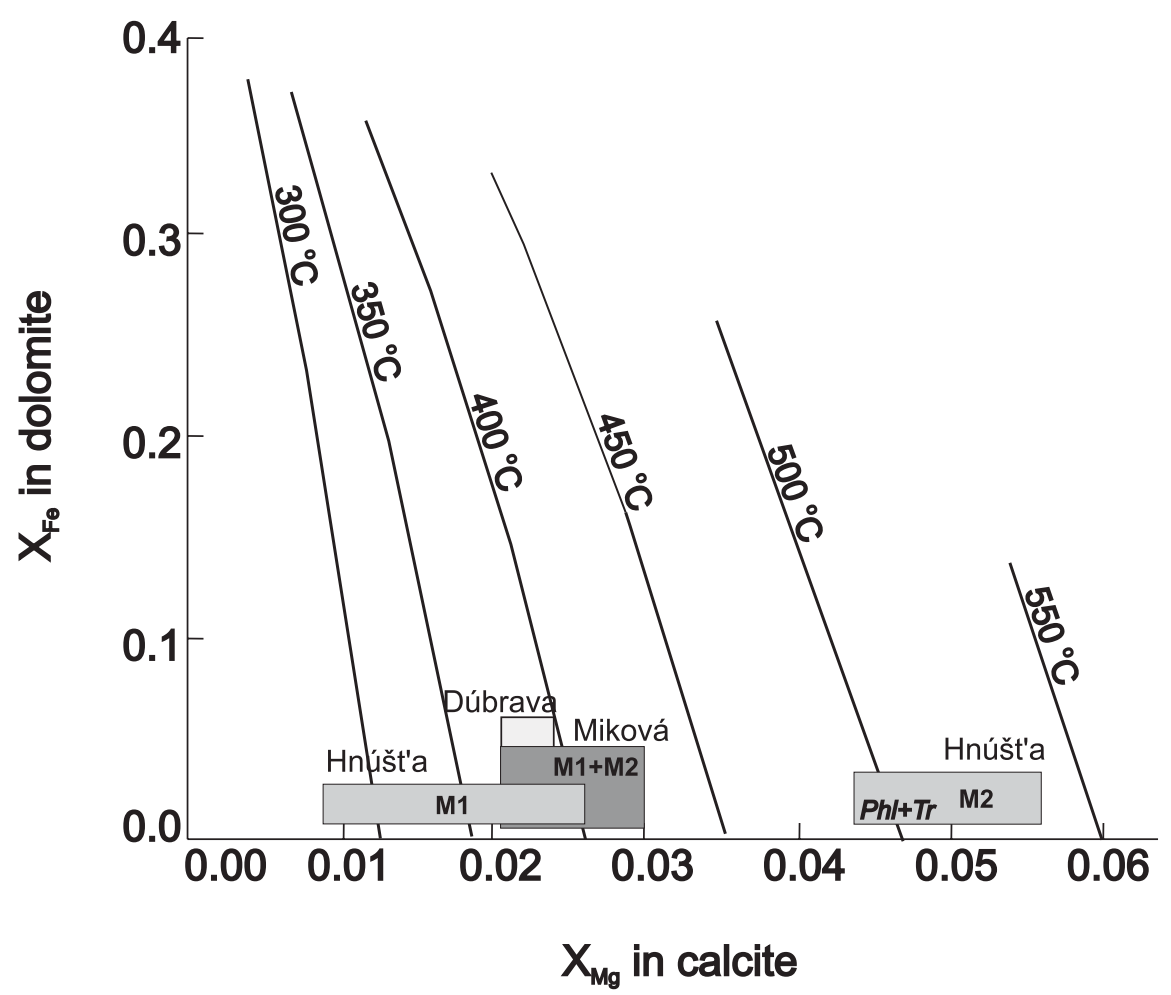

Fig. 6. Diagram of $\mathrm{X}_{\mathrm{Fe}}$-dolomite versus $\mathrm{X}_{\mathrm{Mg}}$-calcite comparing chemical composition of calcite inclusions in the host dolomite (Fig. 4) from Dúbrava (Radvanec and Prochaska, 2001), Miková and Hnúšt'a deposits using the carbonate geothermometry of Powell et al. (1984). M1- older metamorphic event, M2 - younger metamorphic event. $\mathrm{Phl}$ - phlogopite and $\mathrm{Tr}$ - tremolite in dolomite + calcite matrix. 
KODİ RA, P.; RADVANEC, M. Comparative mineralogical and fluid inclusion study of the Hnúšt'a-Mútnik talc-magnesite and Miková-Jedl'ovec magnesite deposit (Western Carpathians, Slovakia)

Table 3: Representative analytical data of silicates from the magnesite and talc bodies of the Hnúšt'aMútnik and the Miková-Jedl'ovec deposits.

\begin{tabular}{|c|c|c|c|c|c|c|c|c|c|c|c|}
\hline \multirow{3}{*}{$\begin{array}{l}\text { Locality } \\
\text { Mineral } \\
\text { Place } \\
\text { Meta. } \\
\text { event }\end{array}$} & \multicolumn{6}{|c|}{ Hnúšt'a-Mútnik talc-magnesite deposit } & \multicolumn{5}{|c|}{ Miková-Jedl'ovec magnesite deposit } \\
\hline & $\begin{array}{c}\text { Czo } \\
\text { matrix }\end{array}$ & $\underset{\text { matrix }}{\mathrm{Zo}}$ & $\begin{array}{c}\operatorname{Tr} \\
\text { Matrix }\end{array}$ & $\begin{array}{c}\text { Phl } \\
\text { matrix }\end{array}$ & $\begin{array}{l}\text { Chl2 } \\
\text { crack }\end{array}$ & $\begin{array}{c}\text { Tlc } \\
\text { crack }\end{array}$ & $\begin{array}{c}\text { Ms } \\
\text { matrix }\end{array}$ & $\begin{array}{c}\text { Ill } \\
\text { in Dol2 }\end{array}$ & $\begin{array}{l}\text { Kln } \\
\text { crack }\end{array}$ & $\begin{array}{l}\mathrm{Chl} 2 \\
\text { crack }\end{array}$ & $\begin{array}{c}\text { Tlc } \\
\text { crack }\end{array}$ \\
\hline & $\begin{array}{c}\text { M2 } \\
\text { prograde }\end{array}$ & $\begin{array}{c}\mathrm{M} 2 \\
\text { prograde }\end{array}$ & $\begin{array}{l}\text { M2 } \\
\text { prograde }\end{array}$ & $\begin{array}{c}\mathrm{M} 2 \\
\text { prograde }\end{array}$ & $\begin{array}{l}\text { M2 } \\
\text { retrog. }\end{array}$ & $\begin{array}{l}\text { M2 } \\
\text { retrog. }\end{array}$ & $\begin{array}{c}\text { M2 } \\
\text { prograde }\end{array}$ & $\begin{array}{c}\text { M2 } \\
\text { prograde }\end{array}$ & $\begin{array}{c}\text { M2 } \\
\text { prograde }\end{array}$ & $\begin{array}{c}\text { M2 } \\
\text { prog.-ret. }\end{array}$ & $\begin{array}{c}\text { M2 } \\
\text { prog.-ret. }\end{array}$ \\
\hline $\mathrm{SiO}_{2}$ & 39.33 & 39.77 & 58.29 & 41.62 & 29.40 & 63.24 & 46.86 & 52.54 & 47.69 & 29.11 & 62.50 \\
\hline $\mathrm{TiO}_{2}$ & 0.07 & 0.04 & 0.02 & 0.55 & 0.04 & 0 & 0.24 & 0.01 & 0 & 0.02 & 0 \\
\hline $\mathrm{Al}_{2} \mathrm{O}_{3}$ & 29.76 & 32.70 & 1.95 & 18.22 & 23.18 & 0.35 & 34.75 & 35.48 & 37.76 & 22.76 & 0.18 \\
\hline $\mathrm{Cr}_{2} \mathrm{O}_{3}$ & 0 & 0 & 0.01 & 0.02 & 0.01 & 0 & 0.02 & 0 & 0.01 & 0.03 & 0.01 \\
\hline $\mathrm{Fe}_{2} \mathrm{O}_{3} *$ & 4.88 & 0.10 & 0 & 0 & 0 & 0 & 0 & 0 & 0 & 0 & 0 \\
\hline $\mathrm{FeO}^{*}$ & 0 & 0 & 1.17 & 1.38 & 3.34 & 0.98 & 0.20 & 0.05 & 0 & 4.87 & 2.21 \\
\hline $\mathrm{MnO}$ & 0.04 & 0.02 & 0.01 & 0 & 0.04 & 0 & 0.01 & 0.01 & 0.01 & 0.05 & 0.03 \\
\hline $\mathrm{MgO}$ & 0.07 & 0.02 & 23.56 & 24.32 & 31.30 & 31.20 & 1.27 & 1.02 & 0.29 & 29.64 & 30.26 \\
\hline $\mathrm{CaO}$ & 24.54 & 24.90 & 13.30 & 0.13 & 0.06 & 0.01 & 0.07 & 0.14 & 0.36 & 0.05 & 0.01 \\
\hline $\mathrm{Na}_{2} \mathrm{O}$ & 0.02 & 0.02 & 0.24 & 0.33 & 0.02 & 0.08 & 0.85 & 0.45 & 0.05 & 0 & 0.06 \\
\hline $\mathrm{K}_{2} \mathrm{O}$ & 0 & 0 & 0.06 & 9.59 & 0.02 & 0 & 10.31 & 4.71 & 0.02 & 0.01 & 0.03 \\
\hline $\mathrm{F}$ & 0 & 0 & 0.75 & 0.79 & 0 & 0.13 & 1.61 & 0.11 & 0.07 & 0.12 & 0 \\
\hline $\mathrm{H}_{2} \mathrm{O}^{*}$ & & & & 3.99 & 12.80 & 4.69 & 3.68 & 4.66 & 13.93 & 12.53 & 4.70 \\
\hline Total & 98.68 & 97.57 & 99.42 & 100.94 & 100.21 & 100.68 & 99.87 & 99.18 & 100.19 & 99.19 & 99.99 \\
\hline $\mathrm{O}=$ & 12.5 & 12.5 & 23.074 & 24 & 36 & 24 & 24 & 24 & 18 & 36 & 24 \\
\hline $\mathrm{Si}$ & 3.010 & 3.026 & 7.880 & 5.711 & 5.508 & 7.972 & 6.252 & 6.682 & 4.095 & 5.549 & 7.976 \\
\hline $\mathrm{Al}$ & & & 0.120 & 2.289 & 2.492 & 0.028 & 1.748 & 1.318 & 0 & 2.451 & 0.024 \\
\hline $\mathrm{Al}$ & 2.682 & 2.930 & 0.190 & 0.656 & 2.623 & 0.024 & 3.711 & 3.996 & 3.819 & 2.658 & 0.003 \\
\hline $\mathrm{Cr}$ & 0 & 0 & 0.001 & 0.002 & 0.001 & 0 & 0.002 & 0 & 0.001 & 0.005 & 0.001 \\
\hline $\mathrm{Ti}$ & 0.004 & 0.002 & 0.002 & 0.057 & 0.006 & 0 & 0.025 & 0.001 & 0 & 0.003 & 0 \\
\hline $\mathrm{Fe}^{3+}$ & 0.281 & 0.006 & 0 & 0 & 0 & 0 & 0 & 0 & 0 & 0 & 0 \\
\hline $\mathrm{Fe}^{2+}$ & 0 & 0 & 0.133 & 0.158 & 0.523 & 0.103 & 0.023 & 0.005 & 0 & 0.776 & 0.236 \\
\hline $\mathrm{Mn}$ & 0.003 & 0.001 & 0 & 0 & 0.006 & 0 & 0.001 & 0.001 & 0.001 & 0.008 & 0.003 \\
\hline $\mathrm{Mg}$ & 0.008 & 0.002 & 4.748 & 4.975 & 8.742 & 5.863 & 0.253 & 0.193 & 0.037 & 8.423 & 5.757 \\
\hline $\mathrm{Ca}$ & 2.010 & 2.030 & 1.926 & 0.022 & 0.012 & 0.001 & 0.010 & 0.019 & 0.033 & 0.010 & 0.001 \\
\hline $\mathrm{Na}$ & 0.003 & 0.003 & 0.063 & 0.088 & 0.007 & 0.020 & 0.219 & 0.111 & 0.008 & 0 & 0.015 \\
\hline K & 0 & 0 & 0.010 & 1.679 & 0.005 & 0 & 1.754 & 0.764 & 0.002 & 0.002 & 0.005 \\
\hline Total & 8.001 & 8.000 & 15.073 & 15.637 & 19.925 & 14.011 & 13.998 & 13.090 & 7.996 & 19.885 & 14.021 \\
\hline CF & 0 & 0 & 0.321 & 0.686 & 0 & 0.104 & 1.358 & 0.088 & 0.038 & 0.145 & 0 \\
\hline $\mathrm{OH}$ & & & & 3.655 & 16 & 3.945 & 3.271 & 3.945 & 7.978 & 15.928 & 0 \\
\hline
\end{tabular}

The third stage of replacement (M2) both with the prograde and retrograde path is mineralogically well distinguished in the Hnúšt'a-Mútnik magnesite-dolomite body. The prograde part produced tremolite and phlogopite but locally also clinozoisite and zoisite (Fig. 9, Table 3). The carbonate geothermometry in samples with young carbonates, tremolite and phlogopite from the Hnúšt'a-Mútnik deposit, showed a relatively high range of temperatures $\left(490^{\circ}\right.$ to $\left.540^{\circ} \mathrm{C}\right)$. These temperatures correspond to the re-equilibration event forming tremolite and phlogopite on the expense of dolomite 1 and calcite 1 during the prograde $\mathrm{M} 2$ process (Fig. 3).

The hipidiomorphic tremolite and phlogopite occur in dolomite matrix with calcite, which crystallized according to the following metamorphic reactions (Fig. 3): a) 5 dolomite +8 quartz $+\mathrm{H}_{2} \mathrm{O}=$ tremolite +3 calcite $+7 \mathrm{CO}_{2} \quad($ Eggert and Kerrick, 1981)

b) dolomite $+\mathrm{K}$-feldspar $+\mathrm{H}_{2} \mathrm{O}=$ phlogopite +3 calcite $+3 \mathrm{CO}_{2} \quad$ (Puhan, 1978)

At the temperature $\mathrm{T}=490-540^{\circ} \mathrm{C}$ (Fig. 6), both reactions had well decomposed dolomite 1 during the prograde M2 metamorphic event. Reactions produced calcite enclosing a chemically homogeneous phase, represented by a mixture of calcite and dolomite $\left(\mathrm{MgCO}_{3}=39.3-42.6, \mathrm{CaCO}_{3}=56.2-59.7 \%\right)$, nearly corresponding to the stoichiometry field of dolomite (Figs. 3 and 7).

The retrograde M2 process (third stage of replacement) locally formed talc and chlorite 2, replacing magnesite along cracks in the Miková- 
Jedl'ovec magnesite body (Fig. 4). Dominant replacement of the former magnesite-dolomite body occurred at Hnúšst'a-Mútnik only forming a talc deposit. On both localities the talc formed according to the following reaction:

c) 3 magnesite $+5 \mathrm{Si}$ rich fluid $\left(\right.$ quartz $\left.+\mathrm{H}_{2} \mathrm{O}\right)=$ talc + quartz $+3 \mathrm{CO}_{2}$

The interstitial-lamella crystalline shapes of quartz and talc, well observable in the Hnúšt'a-Mútnik deposit, are in agreement with the above reaction. In Miková-
Jedl'ovec samples the quartz was secreted inside talc (Fig. 4).

At the end of the third stage of replacement Femagnesite rims used to form. In the matrix in Miková-Jedl'ovec samples rims of $\mathrm{Fe}$-magnesite $\left(\mathrm{FeCO}_{3}=8.9-13.3 \%\right)$ occur on individual grains of magnesite. In Hnúšt'a-Mútnik samples the Femagnesite $\left(\mathrm{FeCO}_{3}=4.6-12.7 \%\right)$ rims are present on talc + quartz + chlorite 2 mineral assemblage (Figs. 4 and 7, Table 2). Fe-magnesite is usually accompanied by pyrite.

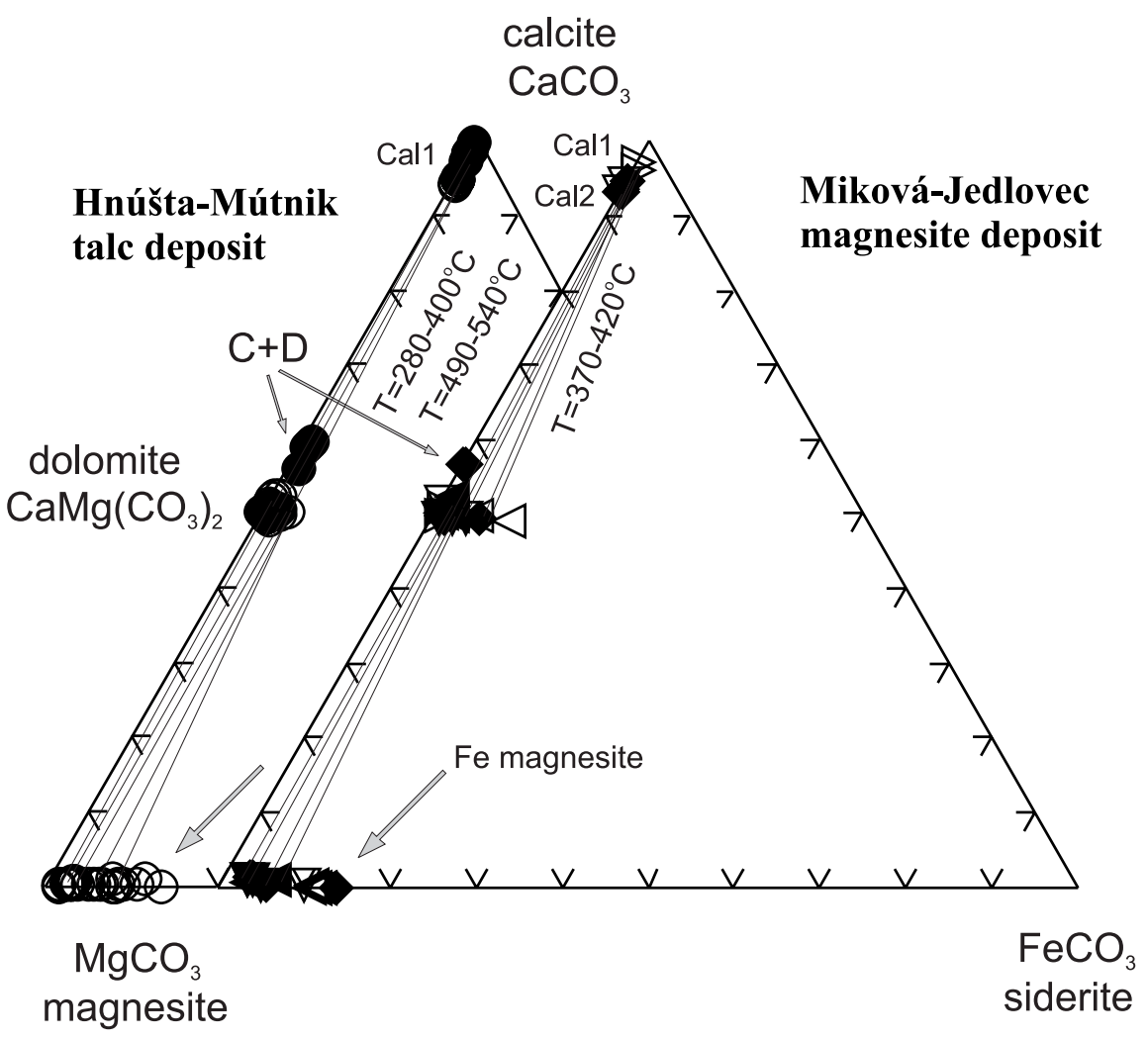

Fig. 7. The nomenclature of carbonates and solid solutions in the system $\mathrm{CaCO}_{3}-\mathrm{MgCO}_{3}$ $\mathrm{FeCO}_{3}$ at temperatures estimated according to the geothermometer by Powell et al. (1984). At the Hnúšt'a-Mútnik the temperature $\left(280-400^{\circ} \mathrm{C}\right)$ is reflected by the relationship of exsolution spots of calcite 1 (Cal1) in dolomite1 (Dol1), representing equilibrium in the prograde part of the M1 process. Prograde part of the M2 process showed here a higher range of temperatures $\left(490-540^{\circ} \mathrm{C}\right)$. At Miková-Jedl'ovec the temperature range $\left(370-420^{\circ} \mathrm{C}\right)$ was established from equilibrated Cal1 and Dol1. The M1 and M2 events could not be well distinguished here from the study of carbonatic matrix. $\mathrm{C}+\mathrm{D}-$ mixture of calcite and dolomite. 


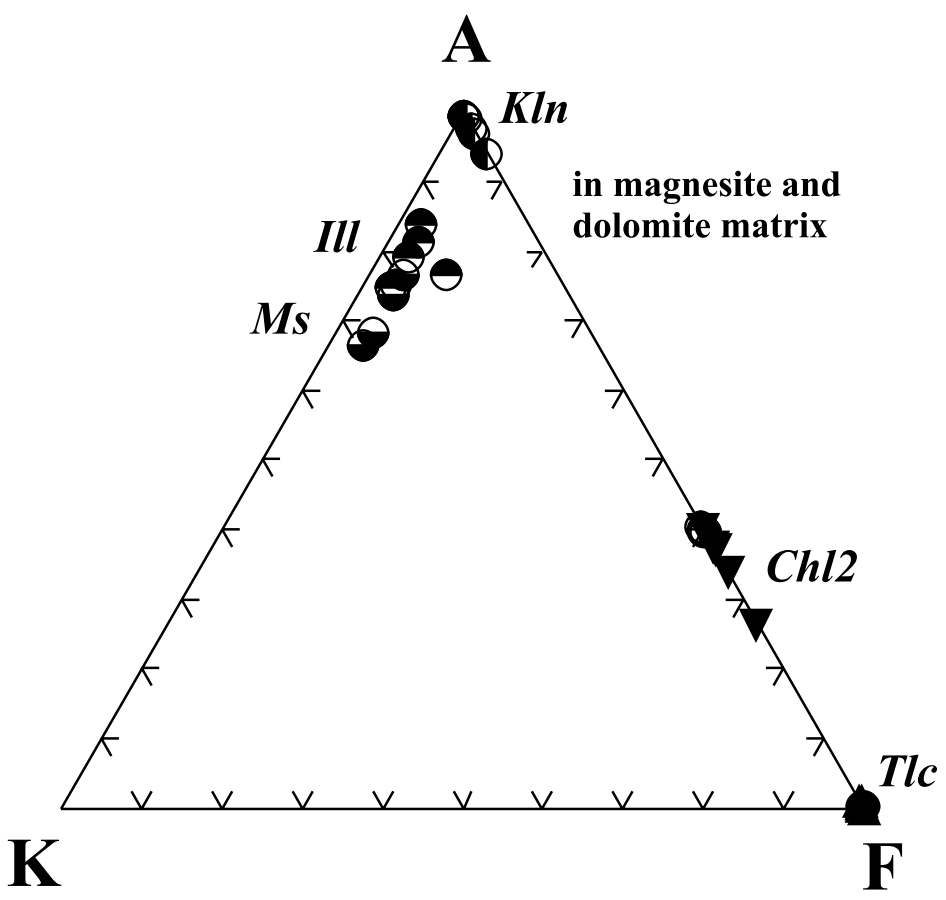

Fig. 8. Chemical classification of mineral assemblages related to M2 process in the AKF triangle. Chlorite $2(\mathrm{Chl} 2)+$ talc (Tlc) assemblage occurs on Hnúšt'aMútnik, replacing host magnesite and dolomite body during the retrograde part of the M2 process. The assemblage phengite $(\mathrm{Ms})+$ illite (Ill) + kaolinite $(\mathrm{Kln})+$ chlorite $2+$ talc occurs on Miková in cracks in host magnesite and dolomite without evidence for a prograde or a retrograde origin. Analyses are presented in Table 3.

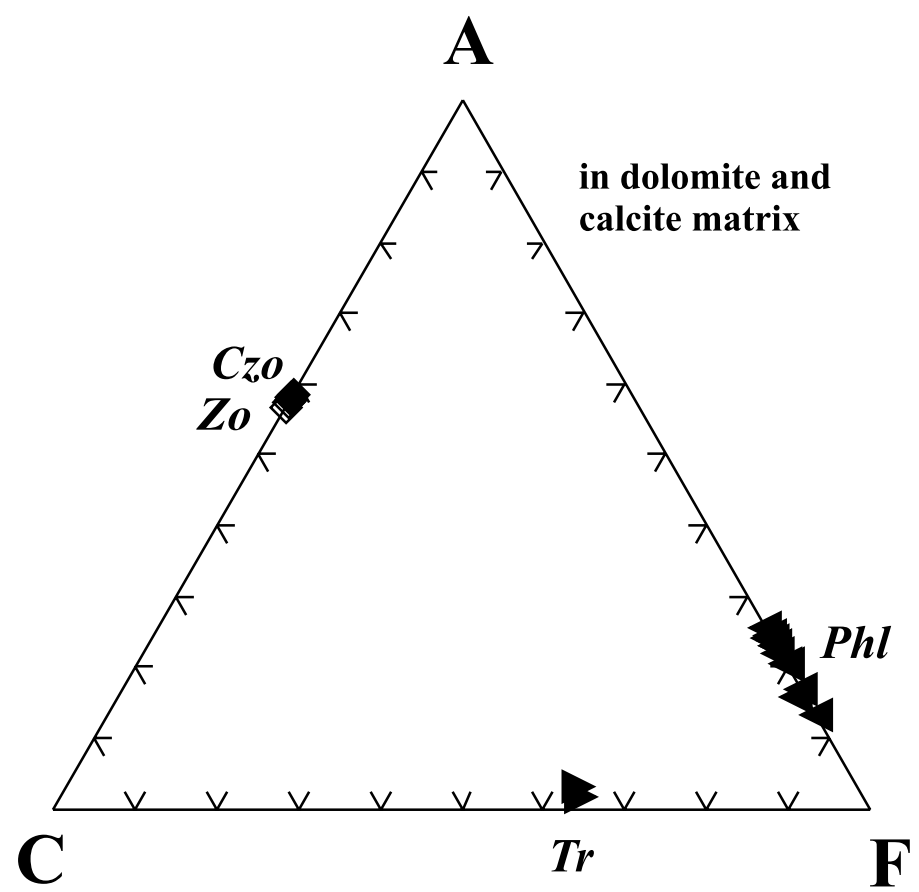

Fig. 9. Chemical classification of the mineral assemblage tremolite $(\mathrm{Tr})+$ phlogopite $(\mathrm{Phl})+$ clinozoisite $(\mathrm{Czo})+$ zoisite $(\mathrm{Zo})$ in the ACF triangle. This prograde M2 mineral assemblage occurs in the matrix of dolomite 1 . Locality Hnúšt'a-Mútnik. Analyses are presented in Table 3. 


\section{Fluid inclusion study}

Preliminary fluid inclusion studies were performed on one sample from the Hnúšt'a-Mútnik - deposit (coarse-grained magnesite representing the M1 process) and two samples from the Miková-Jedl'ovec deposit: coarse-grained magnesite (M1) with some Fe-oxides overprint (M2) and sample with late dolomite 2 and calcite 2 (M2). Based on the optical evaluation these samples have been selected from a variety of samples owing to their best convenience for microthermometric study in terms of the availability of fluid inclusions and their size. In the selected samples fluid inclusions were relatively abundant, but generally less than $10 \mathrm{~mm}$ in size. Where possible, all inclusions were assigned a probable primary or secondary origin according to the criteria of Roedder (1984).

Based on the phase composition at room temperature three main end-member types of fluid inclusions have been recognised (Fig. 10):

- two-phase aqueous inclusions $(\mathrm{L}+\mathrm{V})$, containing aqueous liquid and vapour

- three phase aqueous inclusions $(\mathrm{L}+\mathrm{V}+\mathrm{S})$, containing a solid phase, dissoluble on heating, in addition to aqueous liquid and vapour (occurred in Hnúšst'a-Mútnik samples only)

- three-phase $\mathrm{CO}_{2}$-bearing inclusions $\left(\mathrm{L}_{\mathrm{H} 20}+\mathrm{L}_{\mathrm{CO} 2}+\mathrm{V}\right)$, consisting of two immiscible liquids and a vapour bubble.
In addition, rarely in some of the two-phase inclusions solid phases occur that do not dissolve during heating and thus they can represent captive minerals. Their small size (max. 1-2 $\mu \mathrm{m}$ ) and high birefringence of the host magnesite precluded reliable determining of their optical properties. Therefore their identity is unknown, perhaps they represent some carbonates.

For the same reason neither the optical properties of the solid phase in $\mathrm{L}+\mathrm{V}+\mathrm{S}$ type of inclusions from Hnúšt'a-Mútnik could be unequivocally determined. Perhaps the dissoluble phases represents halite, based on their cubic-like shapes and achromatism in some inclusions, however, in many other inclusions their are also oval and of slightly yellow-greenish colour (Fig. $10 b)$.

\section{Hnúštta-Mútnik deposit}

Microthermometric study of both types of aqueous inclusions $(\mathrm{L}+\mathrm{V}$ and $\mathrm{L}+\mathrm{V}+\mathrm{S})$ proved that they both contain very similar fluids. In several cases, during the cooling and re-heating sequence a small solid crystal, stable at room temperature, formed in the originally twophase inclusions. The presence or absence of daughter minerals in these fluid inclusions is probably just the matter of nucleation difficulties, particularly in small inclusions (Sterner et al., 1988), and/or small variability of fluid composition.

Eutectic temperatures $(\mathrm{Te})$ of both types of aqueous inclusions were in the range -70 to $-40^{\circ} \mathrm{C}$ (Table 4). This
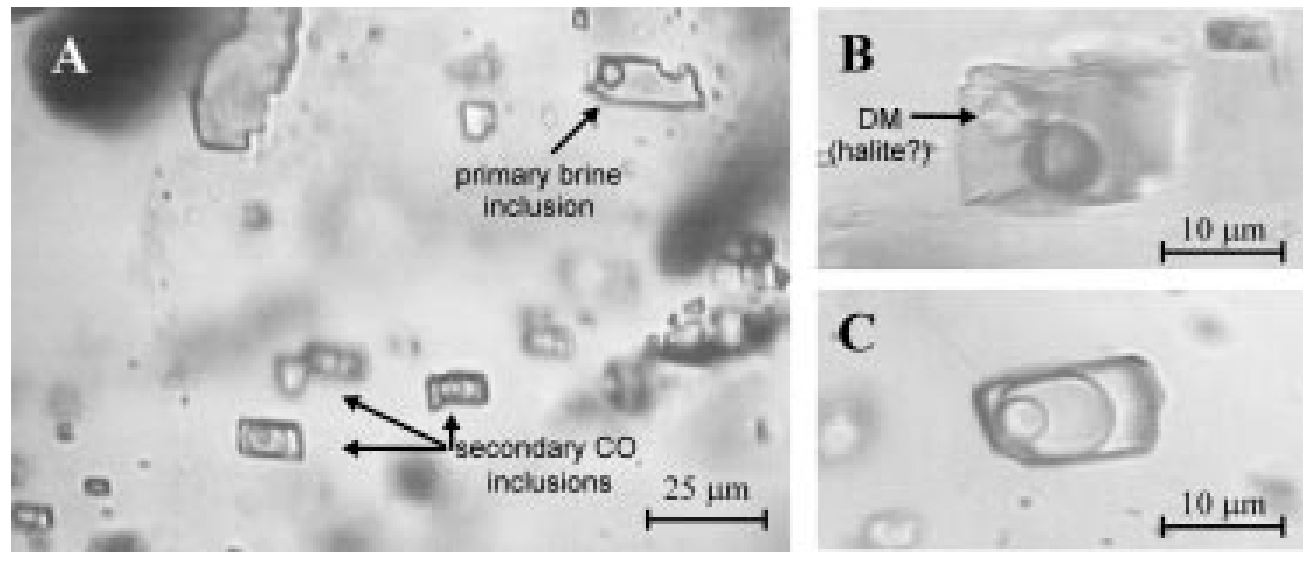

Fig. 10. Microphotographs of fluid inclusions in magnesite. A. Primary two-phase aqueous inclusion and trail of secondary three-phase $\mathrm{CO}_{2}$-bearing inclusions (sample from Miková-Jedl'ovec, Jel-7). B. Typical three phase aqueous inclusion, containing a solid phase, dissoluble on heating (sample from Hnúšt'aMútnik, Hn-7). C. Typical three-phase $\mathrm{CO}_{2}$-bearing inclusion (sample from Hnúšt'a-Mútnik, Hn-7). 
KODİ RA, P.; RADVANEC, M. Comparative mineralogical and fluid inclusion study of the Hnúšt'a-Mútnik talc-magnesite and Miková-Jedl'ovec magnesite deposit (Western Carpathians, Slovakia)

Table 4. Summary of microthermometric data from brine inclusions hosted in magnesite from the Hnúšt'aMútnik deposit.

\begin{tabular}{|c|c|c|c|c|c|c|c|}
\hline Type of FI & & $\begin{array}{l}\mathrm{Te} \\
\left({ }^{\circ} \mathrm{C}\right)\end{array}$ & $\begin{array}{l}\mathrm{Tm}_{\text {ice }} \\
\left({ }^{\circ} \mathrm{C}\right)\end{array}$ & $\begin{array}{c}\text { Tm } \\
\left({ }^{\circ} \mathrm{C}\right)\end{array}$ & $\begin{array}{c}\mathrm{Tm}_{\mathrm{DM}} \\
\left({ }^{\circ} \mathrm{C}\right)\end{array}$ & $\begin{array}{l}\mathrm{Th}_{\mathrm{aq}} \\
\left({ }^{\circ} \mathrm{C}\right)\end{array}$ & $\begin{array}{c}\text { Salinity } \\
\text { (wt } \% \mathrm{NaCl} \text { eq.) }\end{array}$ \\
\hline $\begin{array}{c}\text { brine } \\
(\mathrm{L}+\mathrm{V}, \mathrm{L}+\mathrm{V}+\mathrm{S})\end{array}$ & $\begin{array}{c}{[n]} \\
\text { range } \\
\text { mean }\end{array}$ & $\begin{array}{c}{[5]} \\
-70 \text { to }-40 \\
-\mathbf{4 2}\end{array}$ & $\begin{array}{c}\text { n.d. } \\
\text { (at Te?) }\end{array}$ & $\begin{array}{c}{[6]} \\
-33.5 \text { to }-15.6 \\
\mathbf{- 2 5 . 8}\end{array}$ & $\begin{array}{c}{[5]} \\
126 \text { to } 198 \\
\mathbf{1 6 7}\end{array}$ & $\begin{array}{c}{[8]} \\
299 \text { to } 348 \\
\mathbf{3 3 3}\end{array}$ & $\begin{array}{c}{[5]} \\
28.8 \text { to } 31.8 \\
\mathbf{3 0 . 4}\end{array}$ \\
\hline
\end{tabular}

Notes: Melting temperature of ice was not detected. Possibly the ice was the first dissolving phase on reheating, i.e $\mathrm{Te}=\mathrm{Tm}_{\text {ice }}$ (see text). Salinity is based on halite dissolution temperature, however, it is not entirely clear if the dissolving daughter mineral $\left(\mathrm{Tm}_{\mathrm{DM}}\right)$ is truly halite.

may indicate a substantial presence of $\mathrm{CaCl}_{2}, \mathrm{MgCl}_{2}$ and even $\mathrm{FeCl}_{2}$ in addition to $\mathrm{NaCl}$ in the fluids. The system $\mathrm{NaCl}-\mathrm{CaCl}_{2}-\mathrm{H}_{2} \mathrm{O}$ has stable $\mathrm{Te}-52^{\circ} \mathrm{C}$ and metastable $\mathrm{Te}-70^{\circ} \mathrm{C}$; system $\mathrm{NaCl}-\mathrm{MgCl}_{2}-\mathrm{H}_{2} \mathrm{O}$ has stable $\mathrm{Te}-35^{\circ} \mathrm{C}$ and metastable $\mathrm{Te}$ in the range -37 to $55^{\circ} \mathrm{C}$ and at $-80^{\circ} \mathrm{C}$ (Goldstein and Reinolds, 1994). The system $\mathrm{NaCl}-\mathrm{FeCl}_{2}-\mathrm{H}_{2} \mathrm{O}$ has stable $\mathrm{Te}$ at $-37^{\circ} \mathrm{C}$ (Shepherd et al., 1985). Scattered Te values do not enable to approximate the fluid composition to any of the three-component systems and most likely all of these components are probably present in the fluid.

Upon further re-heating some transparent solid phase used to dissolve in a broad range of temperatures from -33 to $-16^{\circ} \mathrm{C}$. Its identity is not known - it could represent any of the hydrated chlorides of $\mathrm{Na}, \mathrm{Mg}$ or $\mathrm{Ca}$. In addition, some inclusions still contained some other transparent hydrate that was still stable above $0^{\circ} \mathrm{C}$, but soon after further heating it transformed to some different solid. This may represent the change of the unknown hydrate to a less hydrated or unhydrated form of chloride, such as hydrohalite to halite, $\mathrm{CaCl}_{2} \cdot 6 \mathrm{H}_{2} \mathrm{O}$ to $\mathrm{CaCl}_{2} \cdot 4 \mathrm{H}_{2} \mathrm{O}$ (Schiffries, 1990 ), $\mathrm{MgCl}_{2} .8 \mathrm{H}_{2} \mathrm{O}$ to $\mathrm{MgCl}_{2} \cdot 6 \mathrm{H}_{2} \mathrm{O}$ (Spencer et al., 1990) or $\mathrm{FeCl}_{2} \cdot 6 \mathrm{H}_{2} \mathrm{O}$ to $\mathrm{FeCl}_{2} \cdot 4 \mathrm{H}_{2} \mathrm{O}$ (Schimmel, 1928). This transition occurred in both types of aqueous inclusions. Furthermore, one $\mathrm{L}+\mathrm{V}+\mathrm{S}$ inclusion did not freeze at all. Interestingly, dissolution of ice was not observed in any of the inclusions, probably as the result of its complete dissolution at Te or the inclusions had been not frozen completely.

During heating in the $\mathrm{L}+\mathrm{V}+\mathrm{S}$ inclusions the solid phase (halite?) dissolved at 195 and $198^{\circ} \mathrm{C}$, respectively, while in the others (originally metastable $\mathrm{L}+\mathrm{V}$ inclusions) it dissolved in the interval 126 to $167^{\circ} \mathrm{C}$. Vapour-liquid homogenisation occurred in the range 299 to $348^{\circ} \mathrm{C}$. Assuming that the dissolving solid phase was halite the salinities were calculated based on the halite dissolution temperatures, yielding the range 29 to 32 wt $\% \mathrm{NaCl}$ eq. However, note that due to uncertainty of the solid phase identification and the presence of other salts the real total salinity could be significantly different.

$\mathrm{CO}_{2}$-bearing inclusions (Fig. 10c, Table 5) showed melting temperatures always exactly at $-56.6^{\circ} \mathrm{C}$, indicating pure $\mathrm{CO}_{2}$. Clathrate dissolved in the range 5.6 to $3.9^{\circ} \mathrm{C}$, corresponding to salinity 1.4 to $8.0 \mathrm{wt} \%$ $\mathrm{NaCl}$ eq. Partial homogenisation of the $\mathrm{CO}_{2}$-rich phase occurred in the range 26.2 to $30.9^{\circ} \mathrm{C}$ always to liquid $\mathrm{CO}_{2}$, corresponding to $\mathrm{CO}_{2}$ density 0.53 to $0.69 \mathrm{~g} . \mathrm{cm}^{-3}$. Total homogenisation temperature (Th) was not always possible to measure due to decrepitation of some inclusions before Th was reached. However, more than half of the inclusions survived the heating up to the total homogenisation at 307 to $336^{\circ} \mathrm{C}$ (always to $\mathrm{CO}_{2}$ phase). Calculated bulk composition and density of included fluid is summarised in table 5 .

Aqueous brine inclusions and $\mathrm{CO}_{2}$-rich inclusions occur often in the same magnesite crystals and show similar range of final homogenisation temperatures, indicating a possibility of immiscible coexistence of both types of fluids. However, if the fluids had really coexisted a whole range of inclusions with variable proportions of both contrasting types of fluids should have occurred, resulting in scattered degree of filling, homogenisation temperatures and compositions (Ramboz et al., 1982). However, just one inclusion has been found that seems to capture a heterogeneous mixture of both fluids (Table 4) but this can result just from subsequent partial refilling of the inclusion, e.g. $\mathrm{CO}_{2}$ fluid after brine. Unfortunately, the age relationship of both types of inclusions in note entirely clear. Both types sometimes appear to be primary and sometimes secondary (Fig. 11) but generally, $\mathrm{CO}_{2}-$ rich inclusions occur as secondary trails more often then the brine inclusions. 
KODÌ RA, P.; RADVANEC, M. Comparative mineralogical and fluid inclusion study of the Hnúšt'a-Mútnik talc-magnesite and Miková-Jedl'ovec magnesite deposit (Western Carpathians, Slovakia)

Table 5. Summary of microthermometric data from $\mathrm{CO}_{2}$-rich inclusions hosted in magnesite from the Hnúšt'a-Mútnik deposit.

\begin{tabular}{|c|c|c|c|c|c|c|c|c|c|c|c|}
\hline $\begin{array}{l}\text { Type } \\
\text { of FI }\end{array}$ & & $\begin{array}{c}\mathrm{Tm}_{\mathrm{CO} 2} \\
\left({ }^{\circ} \mathrm{C}\right)\end{array}$ & $\begin{array}{c}\operatorname{Tm}_{\text {clathrate }} \\
\left({ }^{\circ} \mathrm{C}\right)\end{array}$ & $\begin{array}{c}\mathrm{Th}_{\mathrm{CO} 2} \\
\left({ }^{\circ} \mathrm{C}\right)\end{array}$ & $\begin{array}{l}\mathrm{Th}_{\text {tot }} \\
\left({ }^{\circ} \mathrm{C}\right)\end{array}$ & $\begin{array}{c}\text { Salinity } \\
\text { (wt } \% \\
\mathrm{NaCl} \text { eq. })\end{array}$ & $\begin{array}{c}\mathrm{CO}_{2} \\
\text { density } \\
\left(\mathrm{g} \mathrm{cm}^{-3}\right)\end{array}$ & $\begin{array}{c}\text { Bulk } \\
\text { density } \\
\left(\mathrm{g} \mathrm{cm}^{-3}\right)\end{array}$ & $\mathrm{X}_{\mathrm{CO} 2}$ & $\mathrm{X}_{\mathrm{H} 2 \mathrm{O}}$ & $\mathrm{X}_{\mathrm{NaCl}}$ \\
\hline $\begin{array}{l}\mathrm{CO}_{2^{-}} \\
\text {rich }\end{array}$ & $\begin{array}{c}{[n]} \\
\text { range } \\
\text { mean }\end{array}$ & $\begin{array}{l}{[15]} \\
\mathbf{- 5 6 . 6} \\
-56.6\end{array}$ & $\begin{array}{c}{[15]} \\
5.6 \text { to } 9.3 \\
\mathbf{8 . 5}\end{array}$ & $\begin{array}{c}{[15]} \\
26.2 \text { to } 30.9 \\
\mathbf{2 9 . 3}\end{array}$ & $\begin{array}{c}{[8]} \\
307 \text { to } 336 \\
\mathbf{3 1 8}\end{array}$ & $\begin{array}{c}{[15]} \\
1.4 \text { to } 8.0 \\
\mathbf{2 . 0}\end{array}$ & $\begin{array}{c}{[15]} \\
0.53 \text { to } 0.69 \\
\mathbf{0 . 6 2}\end{array}$ & $\begin{array}{c}{[8]} \\
0.67 \text { to } 0.80 \\
\mathbf{0 . 7 6}\end{array}$ & $\begin{array}{c}{[8]} \\
0.27 \text { to } 0.50 \\
\mathbf{0 . 2 8}\end{array}$ & $\begin{array}{c}{[8]} \\
0.50 \text { to } 0.72 \\
\mathbf{0 . 7 2}\end{array}$ & $\begin{array}{c}{[8]} \\
0.00 \text { to } 0.01 \\
\mathbf{0 . 0 0}\end{array}$ \\
\hline mixed & {$[n]$} & $\begin{array}{c}{[1]} \\
-56.6\end{array}$ & $\begin{array}{c}{[1]} \\
-4 \\
\end{array}$ & $\begin{array}{l}{[1]} \\
29.6\end{array}$ & $\begin{array}{l}{[1]} \\
432\end{array}$ & $\begin{array}{l}{[1]} \\
19.6\end{array}$ & $\begin{array}{l}{[1]} \\
0.61\end{array}$ & $\begin{array}{l}{[1]} \\
0.94\end{array}$ & $\begin{array}{l}{[1]} \\
0.13\end{array}$ & $\begin{array}{l}{[1]} \\
0.81\end{array}$ & $\begin{array}{l}{[1]} \\
0.06\end{array}$ \\
\hline
\end{tabular}

Note: Mixed type of fluid inclusions possibly represents inclusions heterogeneously capturing brine and $\mathrm{CO}_{2}$-rich fluid.

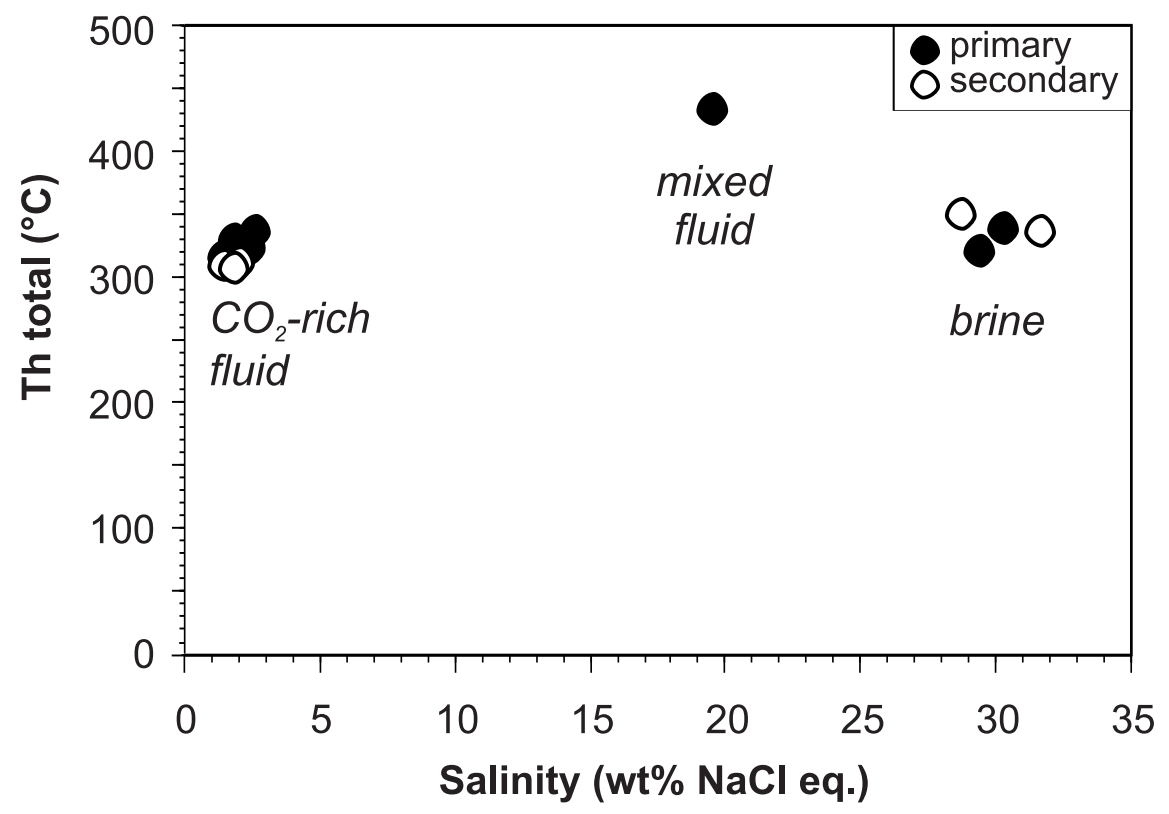

Fig. 11. Final homogenisation temperatures (Th total) vs. salinity diagram for fluid inclusions in magnesite from the Hnúšt'a-Mútnik deposit.

\section{Miková-Jedl'ovec}

Aqueous inclusions from the Miková-Jedl'ovec deposit can be divided into two subtypes, based on the behaviour during microthermometric measurements and corresponding contrasting salinities. The first group can be described as saline brine inclusions, occurring in magnesite only, while the others are low salinity inclusions, occurring as secondary inclusions in magnesite and as primary and secondary inclusions in dolomite 2.

Brine inclusions (Table 6) showed very low eutectic temperatures, ranging from -75 to $-49^{\circ} \mathrm{C}$ and indicating a significant presence of $\mathrm{CaCl}_{2}$ and/or $\mathrm{MgCl}_{2}$ in addition to $\mathrm{NaCl}$ in the fluids (Goldstein and Reinolds, 1994). Further re-heating resulted in subsequent dissolution of the homogeneous, fine-grained content of inclusions, while the last tiny crystal dissolved in the range -20 to $14^{\circ} \mathrm{C}$ (Fig. 12). This phase was most probably some hydrate, based on optical properties and behaviour on dissolution (transparent with low relief, did not attach the vapour bubble). More data have been obtained thanks to the use of the cooling-heating cycling technique (Haynes, 1985). This technique enabled to grow two or three different, large, single-crystal solids in inclusions. Then their temperature of melting could 
KODİ RA, P.; RADVANEC, M. Comparative mineralogical and fluid inclusion study of the Hnúšt'a-Mútnik talc-magnesite and Miková-Jedl'ovec magnesite deposit (Western Carpathians, Slovakia)

be reproducibly measured (Fig. 12). Ice was always the first of the solids that completely dissolved (in the range -34 to $-24^{\circ} \mathrm{C}$ ) and next, the transparent hydrate dissolved $\left(-20\right.$ to $\left.-12.5^{\circ} \mathrm{C}\right)$. Finally, where the third solid was present, it used to dissolve in the range from -12 to $8^{\circ} \mathrm{C}$. However, the latest phase was possible to grow just in a part of the brine inclusion, possibly due to the nucleation difficulties. This solid had rhombic habit, slightly yellowish colour and a bit higher relief than the earlier hydrate. The identity of both of the solids other than ice is not clear. According to the low Te values the unknown phases could represent hydrates of $\mathrm{NaCl}$ (hydrohalite), $\mathrm{CaCl}_{2}$ (antarctite $\mathrm{CaCl}_{2} \cdot 6 \mathrm{H}_{2} \mathrm{O}$ ) and/or $\mathrm{MgCl}_{2}\left(\mathrm{MgCl}_{2} \cdot 12 \mathrm{H}_{2} \mathrm{O}\right.$ or $\left.\mathrm{MgCl}_{2} \cdot 8 \mathrm{H}_{2} \mathrm{O}\right)$. However, all these three hydrates are transparent with similar optical properties (Shepherd et al., 1985) and consequently they can not be identified without any advanced analytical methods (e.g. Laser Raman). In addition the slightly yellowish colour of the later solid may also indicate the presence of an Fe-bearing chloride, such as $\mathrm{FeCl}_{2} \cdot 6 \mathrm{H}_{2} \mathrm{O}$. Increased amount of $\mathrm{Fe}$ in the fluid can correspond to the Fe-oxides overprint of the studied sample.

Table 6: Summary of microthermometric data from aqueous inclusions hosted in magnesite and dolomite 2. From the Miková-Jedl'ovec deposit.

\begin{tabular}{|c|c|c|c|c|c|c|c|}
\hline Type of FI & & $\begin{array}{l}\mathrm{Te} \\
\left({ }^{\circ} \mathrm{C}\right)\end{array}$ & $\begin{array}{c}\mathrm{Tm}_{\text {ice }} \\
\left({ }^{\circ} \mathrm{C}\right)\end{array}$ & $\begin{array}{c}\mathrm{Tm} \\
\left({ }^{\circ} \mathrm{C}\right)\end{array}$ & $\begin{array}{c}\mathrm{Tm} \\
\left({ }^{\circ} \mathrm{C}\right)\end{array}$ & $\begin{array}{l}\mathrm{Th}_{\mathrm{aq}} \\
\left({ }^{\circ} \mathrm{C}\right)\end{array}$ & $\begin{array}{c}\text { Salinity } \\
\text { (wt } \% \\
\mathrm{NaCl} \text { eq.) }\end{array}$ \\
\hline $\begin{array}{l}\text { aqueous brine } \\
(\mathrm{L}+\mathrm{V})\end{array}$ & $\begin{array}{l}{[n]} \\
\text { range } \\
\text { mean }\end{array}$ & $\begin{array}{c}{[13]} \\
-75 \text { to }-49 \\
\mathbf{- 6 3 . 5}\end{array}$ & $\begin{array}{c}{[14]} \\
-33.8 \text { to }-23.6 \\
\mathbf{- 2 4 . 8}\end{array}$ & $\begin{array}{c}{[14]} \\
-20.0 \text { to }-12.5 \\
\mathbf{- 1 7 . 4}\end{array}$ & $\begin{array}{c}5] \\
-12.0 \text { to }-8.3 \\
\mathbf{- 1 0 . 8}\end{array}$ & $\begin{array}{c}{[14]} \\
195 \text { to } 248 \\
\mathbf{2 2 0}\end{array}$ & $\begin{array}{c}{[14]} \\
23.3 \text { to } 24.4 \\
\mathbf{2 3 . 7}\end{array}$ \\
\hline $\begin{array}{l}\text { aqueous low } \\
\text { salinity } \\
(\mathrm{L}+\mathrm{V})\end{array}$ & $\begin{array}{c}{[n]} \\
\text { range } \\
\text { mean }\end{array}$ & $\begin{array}{c}{[2]} \\
-30 \text { to }-25\end{array}$ & $\begin{array}{c}{[6]} \\
-5.3 \text { to }-1.5 \\
-\mathbf{3 . 6} \\
\end{array}$ & n.d. & n.d. & $\begin{array}{c}{[6]} \\
132 \text { to } 249 \\
\mathbf{2 0 3}\end{array}$ & $\begin{array}{c}{[6]} \\
2.6 \text { to } 8.3 \\
\mathbf{5 . 7}\end{array}$ \\
\hline
\end{tabular}

Notes: Two separate hydrates were possible to grow on heating: transparent (hydr1) and yellowish (hydr2). Salinity is based on dissolution temperature of the transparent hydrate that is assumed to have been hydrohalite.

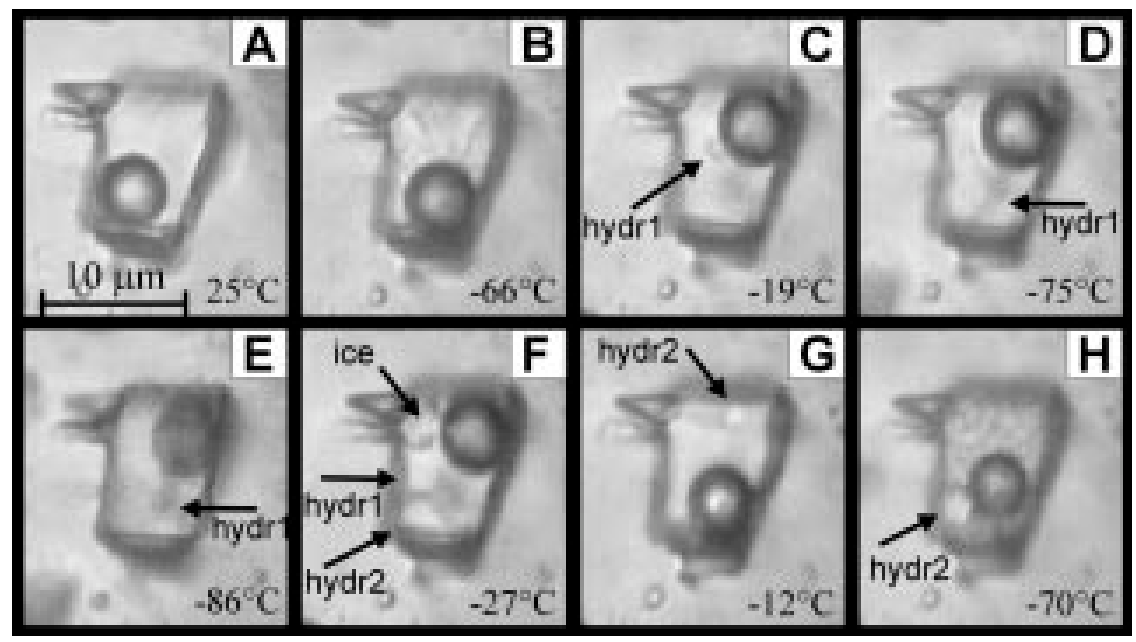

Fig. 12. Sequence of microphotographs documenting typical changes in appearance of a two-phase aqueous brine inclusion from the Miková-Jedl'ovec deposit (Jel-7). A. Room temperature appearance. B. The inclusions froze at $-65^{\circ} \mathrm{C}$ into mass of fine-grained solids. C. Re-heating: low relief hydrate (possibly hydrohalite) was the last remaining solid, finally dissolving at $-17.4^{\circ} \mathrm{C}$. D. If the inclusion was cooled again just before hydr1 dissolution the hydr1 had grown. E. At $-85^{\circ} \mathrm{C}$ the liquid in the inclusion froze. Note the much darker (brownish) colour of the frozen mass compared to that in photo B. F. Re-heating and cycling enabled to grow three different solids (ice, hydr1 and yellowish higher relief hydrate 2). Ice dissolved at $-26.1^{\circ} \mathrm{C}$, hydr 1 at $-15.7^{\circ} \mathrm{C}$. G. Hydr 2 finally dissolved at $-9.0^{\circ} \mathrm{C}$. H. If the inclusion was cooled again just before hydr 2 dissolution the hydr 2 had growm and the remaining fluid froze at $-70^{\circ} \mathrm{C}$. The identity of both hydrates is not entirely clear (see text). 
Anyway, the composition of the brine is very complex and due to the much higher solubility of $\mathrm{Mg}$, $\mathrm{Ca}$ and $\mathrm{Fe}$ chlorides, compared to the solubility of $\mathrm{NaCl}$, the $\mathrm{NaCl} /$ other chlorides ratio must be very low. This is in agreement with the data on chemical composition of fluid inclusions determined from the Dúbrava deposit magnesites (Radvanec and Prochaska, 2001). However, the ignorance about the identity of the dissolving solids does not allow correct calculation of the total salinity of fluids. A rough approximation can be performed based on the assumption that the transparent hydrate was hydrohalite, resulting in the apparent salinity 23.3 to $24.4 \mathrm{wt} \% \mathrm{NaCl}$ eq. Final liquid-vapour homogenisation occurred in the range 195 to $248^{\circ} \mathrm{C}$.

The low salinity aqueous inclusions (Table 6) showed much simple behaviour during microthermometric measurements. Due to the low salinity and small size of inclusions the eutectic temperature was possible to measure just in two inclusions $\left(-30\right.$ and $\left.-25^{\circ} \mathrm{C}\right)$, corresponding to metastable eutectic of the system $\mathrm{NaCl}-\mathrm{KCl}-\mathrm{H}_{2} \mathrm{O}$ (Goldstein and Reinolds, 1994). Ice melting occurred in the range from -5.3 to $-1.5^{\circ} \mathrm{C}$, resulting in salinity 2.6 to $8.3 \mathrm{wt} \% \mathrm{NaCl}$ eq. Liquid-vapour homogenisation was reached from 132 to $249^{\circ} \mathrm{C}$.

$\mathrm{CO}_{2}$-bearing inclusions (Table 7) are present in both the magnesite and dolomite samples and appear nearly always secondary (Fig. 10a). Melting temperatures of these inclusions varied in the range from -56.8 to $56.5^{\circ} \mathrm{C}$, suggesting nearly pure $\mathrm{CO}_{2}$ in the fluid. Clathrate dissolved in the range 7.3 to $8.8^{\circ} \mathrm{C}$, corresponding to salinity 2.4 to $4.0 \mathrm{wt} \% \mathrm{NaCl}$ eq. Partial homogenisation of the $\mathrm{CO}_{2}$-rich phase was measured in the range 26.3 to $28.8^{\circ} \mathrm{C}$ always to liquid $\mathrm{CO}_{2}$, corresponding to $\mathrm{CO}_{2}$ density 0.64 to $0.69 \mathrm{~g} . \mathrm{cm}^{-3}$. More than half of the inclusions survived the heating up to the total homogenisation at 318 to $332^{\circ} \mathrm{C}$ (always to $\mathrm{CO}_{2}$ phase), the rest decrepitated before the Th was reached. Calculated bulk composition and density of included fluid is shown in table 7.

In addition, a few other inclusions have been measured containing a fluid with some $\mathrm{CO}_{2}$ content and increased amount of dissolved salts, such as they could represent a mixture of both brines and $\mathrm{CO}$-rich fluids (Table 7, Fig. 13). However, due to much different homogenisation temperatures of both types of fluids and their clear age relationship, heterogeneous trapping of coexisting fluids can be excluded. More likely, they can result from subsequent partial refilling of former brine inclusions by $\mathrm{CO}_{2}$ fluid, e.g. on crosscuttings of primary brine inclusions with secondary $\mathrm{CO}_{2}$ inclusion planes.

\section{P-T conditions, discussion and conclusions}

Comparative mineralogical and fluid inclusion study of two type localities, located in different geological units produced new important data about the process of the origin of magnesite and magnesite-talc mineralisation in Western Carpathians.

Based on detailed mineralogical, petrological and geochemical study main mineral assemblages and sequences of successive crystallisation within M1 and M2 metamorphic events have been determined. On both localities magnesite mineralisation has formed during two stages of replacement, both corresponding to the M1 metamorphic process. During the first stage dolomite1 and calcite1 has formed on the expense of sedimentary calcite of protolithic limestone. The second (major) stage is characterized by crystallization of major amount of magnesite. The third stage of replacement

Table 7: Summary of microthermometric data from $\mathrm{CO}_{2}$-rich inclusions hosted in magnesite and dolomite 2. from the Miková-Jedl'ovec deposit.

\begin{tabular}{|c|c|c|c|c|c|c|c|c|c|c|c|}
\hline $\begin{array}{l}\text { Type } \\
\text { of FI }\end{array}$ & & $\begin{array}{c}\mathrm{Tm}_{\mathrm{CO} 2} \\
\left({ }^{\circ} \mathrm{C}\right)\end{array}$ & $\begin{array}{c}\mathrm{Tm}_{\text {clathrate }} \\
\left({ }^{\circ} \mathrm{C}\right)\end{array}$ & $\begin{array}{c}\mathrm{Th}_{\mathrm{CO} 2} \\
\left({ }^{\circ} \mathrm{C}\right)\end{array}$ & $\begin{array}{l}\mathrm{Th}_{\text {tot }} \\
\left({ }^{\circ} \mathrm{C}\right)\end{array}$ & $\begin{array}{c}\text { Salinity } \\
\text { (wt } \% \\
\mathrm{NaCl} \text { eq.) }\end{array}$ & $\begin{array}{c}\mathrm{CO}_{2} \\
\text { density } \\
\left(\mathrm{g} \mathrm{cm}^{-3}\right)\end{array}$ & $\begin{array}{c}\text { Bulk } \\
\text { density } \\
\left(\mathrm{g} \mathrm{cm}^{-3}\right)\end{array}$ & $\mathrm{X}_{\mathrm{CO} 2}$ & $\mathrm{X}_{\mathrm{H} 2 \mathrm{O}}$ & $\mathrm{X}_{\mathrm{NaCl}}$ \\
\hline $\begin{array}{l}\mathrm{CO}_{2-}^{-} \\
\text {rich }\end{array}$ & $\begin{array}{l}{[n]} \\
\text { range } \\
\text { mean }\end{array}$ & $\begin{array}{c}{[7]} \\
-56.8 \text { to }-56.5 \\
-\mathbf{5 6 . 7}\end{array}$ & $\begin{array}{c}{[7]} \\
7.3 \text { to } 8.8 \\
\mathbf{8 . 8}\end{array}$ & $\begin{array}{c}{[7]} \\
26.3 \text { to } 28.8 \\
\mathbf{2 7 . 8}\end{array}$ & $\begin{array}{c}{[4]} \\
318 \text { to } 332 \\
\mathbf{3 2 2}\end{array}$ & $\begin{array}{c}{[7]} \\
2.4 \text { to } 4.0 \\
\mathbf{2 . 4}\end{array}$ & $\begin{array}{c}{[7]} \\
0.64 \text { to } 0.69 \\
\mathbf{0 . 6 6}\end{array}$ & $\begin{array}{c}{[4]} \\
0.78 \text { to } 0.82 \\
\mathbf{0 . 8 0}\end{array}$ & $\begin{array}{c}{[4]} \\
0.28 \text { to } 0.40 \\
\mathbf{0 . 2 9}\end{array}$ & $\begin{array}{c}{[4]} \\
0.60 \text { to } 0.72 \\
\mathbf{0 . 7 1}\end{array}$ & $\begin{array}{l}{[8]} \\
0.01 \\
\mathbf{0 . 0 1}\end{array}$ \\
\hline mixed & $\begin{array}{l}{[n]} \\
\text { range } \\
\text { mean }\end{array}$ & $\begin{array}{c}{[3]} \\
-56.8 \text { to }-56.5 \\
\mathbf{- 5 6 . 8}\end{array}$ & $\begin{array}{c}{[4]} \\
-0.5 \text { to } 2.8 \\
\mathbf{1 . 2}\end{array}$ & $\begin{array}{c}{[2]} \\
30.3 \text { to } 30.4\end{array}$ & $\begin{array}{c}{[4]} \\
236 \text { to } 450 \\
\mathbf{3 9 1}\end{array}$ & $\begin{array}{c}{[4]} \\
12.2 \text { to } 16.2 \\
\mathbf{1 4 . 3}\end{array}$ & $\begin{array}{l}{[2]} \\
0.58\end{array}$ & $\begin{array}{c}{[2]} \\
0.77 \text { to } 0.82\end{array}$ & $\begin{array}{c}{[2]} \\
0.22 \text { to } 0.30\end{array}$ & $\begin{array}{c}{[2]} \\
0.67 \text { to } 0.74\end{array}$ & $\begin{array}{c}{[2]} \\
0.03 \text { to } 0.04\end{array}$ \\
\hline
\end{tabular}

Note: Mixed type of fluid inclusions possibly represents inclusions heterogeneously capturing brine and $\mathrm{CO}_{2}$-rich fluid. 


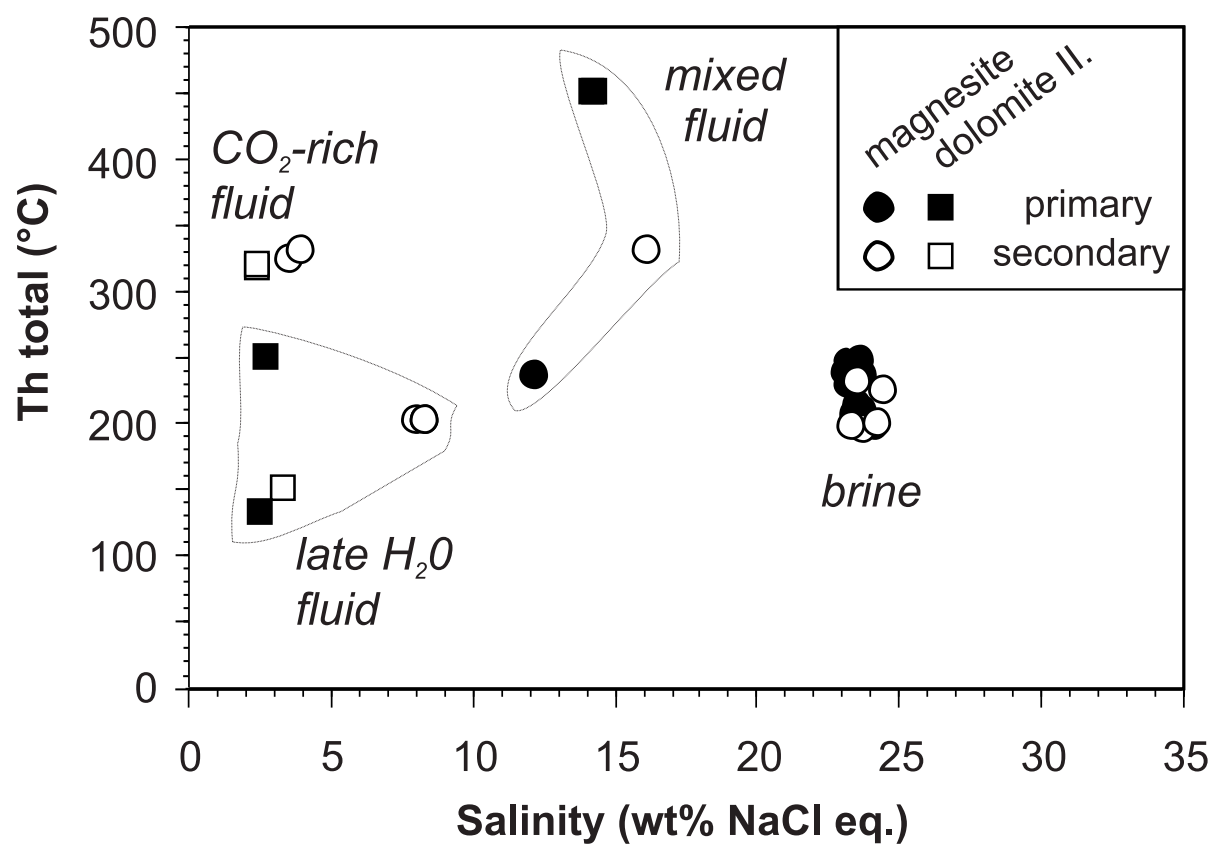

Fig. 13. Final homogenisation temperatures (Th total) vs. salinity diagram for fluid inclusions in magnesite and dolomite 2. from the Miková-Jedl'ovec deposit.

corresponds to the younger M2 metamorphic process and is represented especially by dolomite 2 , talc, chlorite, pyrite and further accompanied by tremolite, phlogopite, clinozoisite, zoisite at Hnúšsta-Mútnik and goethite at Miková-Jedl'ovec. Talc, tremolite and phlogopite formed on the expense of magnesite and dolomite respectively. The third stage is much better developed at the Hnúšt'a-Mútnik deposit than at Miková-Jedl'ovec.

Microthermometric measurements of fluid inclusions in magnesite in samples from both localities showed the presence of primary brine inclusions, representing magnesite-forming fluids. A relatively "exotic" composition (low $\mathrm{NaCl} /$ other salts ratio) of these brine inclusions is in agreement with the data on chemical composition of fluid inclusions in magnesite from the Dúbrava deposit (Radvanec and Prochaska, 2001) and from several magnesite deposits in Austria (Prochaska, 2001). Consequently, this supports their model for the formation of magnesite from highly evolved evaporated marine waters replacing (attacking) limestones. Advanced evaporation and associated extreme fractionation is one of the most probable mechanisms that can produce the observed type of fluid. Large amounts of evaporitic brines in the Gemericum unit had been generated only during Upper Permian including the Permian boundary with Lower Triassic.

Microthermometry showed that the brines forming magnesite at Miková-Jedl'ovec are slightly less saline and homogenised at lower temperatures than the brines from Hnúšt'a-Mútnik. On the other hand, $\mathrm{CO}_{2}$-rich inclusions showed nearly identical parameters of the fluids at both deposits (density, salinity, Th values and corresponding isochores), suggesting a common history of fluid evolution. $\mathrm{CO}_{2}$ fluids can result from thermal decarboxylation of organic acids and from dissolution of rock-forming carbonates during progressive metamorphism and replacement reactions. The timing of these inclusions is not entirely clear, they could have been captured either during the stage 2 and/or during the stage 3 (release of $\mathrm{CO}_{2}$ from magnesites replaced by talc).

Low salinity aqueous fluid inclusions occurring at Miková-Jedl'ovec are younger than brines and probably also younger than the $\mathrm{CO}_{2}$-rich fluid. Their composition, determined by microthermometry (diluted $\mathrm{NaCl}-\mathrm{KCl}$ waters), is again well in agreement with the chemical composition of fluids determined from inclusions in dolomite 2 from the Dúbrava deposit. (Radvanec and Prochaska, 2001). Consequently this fluid is probably 
related to the M2 process (stage 3 of replacement), corresponding to the origin of talc.

Fluid inclusion microthermometry and carbonate geothermometry (Figs. 6 and 7) provide some limited information about PT conditions of origin of studied mineralisations. Carbonate geothermometry provided information about temperatures of the first stage of replacement: $280^{\circ} \mathrm{C}$ to $400^{\circ} \mathrm{C}$ at the Hnúšt'a-Mútnik deposit and 370 to $420^{\circ} \mathrm{C}$ at the Miková-Jedl'ovec deposit. In addition, temperature range of the third stage of replacement (M2 process) was determined for the HnúšstaMútnik deposit: 490 to $540^{\circ} \mathrm{C}$ in the prograde stage.

Fluid inclusions provided some additional pressure and temperature limits related to the second and partially to the third stage of replacement, but no data exist for the initial stage.

Calculation of minimum pressure at final homogenisation temperatures derived from fluid inclusions from the Hnúšsta-Mútnik deposit has been calculated and plotted in Fig. 12, together with corresponding isochores. The PT interpretations represent conditions during the origin of the hosting magnesite, i.e. during the second stage of replacement. Temperature and pressure conditions of trapping could be located anywhere along the isochores, starting from the minimum values at homogenisation temperatures $\left(\sim 330^{\circ} \mathrm{C} / 12 \mathrm{MPa}\right.$ for brines and $\sim 320^{\circ} \mathrm{C} / 109 \mathrm{MPa}$ for $\mathrm{CO}_{2}$ fluid). However, note that the PT calculations related to brines can bear some error due to the uncertainties in the brine composition. In Fig. 12 the isochores fields overlap in the PT range $450-600^{\circ} \mathrm{C}$ and 200-400MPa. If the two fluids had really co-existed these values would represent the trapping conditions, but as discussed above, the simultaneous trapping has not been proven. Alternatively, the $\mathrm{CO}_{2}$ fluid can be related to the M2 process (stage three of replacement). In that case the temperature range obtained from the independent carbonate geothermometer fixes positions along isochores and thus defines trapping pressures in the range 240 to $330 \mathrm{MPa}$ (Fig. 14).

Minimum pressure conditions at final homogenisation temperatures and corresponding fields of isochores for the Miková-Jedl'ovec deposit are plotted in Fig. 15. Trapping of fluids could have occurred anywhere along the isochores, i.e. anywhere inside the isochores fields. The minimum PT values of trapping are $\sim 220^{\circ} \mathrm{C} / 2 \mathrm{MPa}$ for brines, 132 to $249^{\circ} \mathrm{C} / 1 \mathrm{MPa}$ for low salinity aqueous fluids and $\sim 322^{\circ} \mathrm{C} / 128 \mathrm{MPa}$ for $\mathrm{CO}_{2}$ fluid. The PT data for brines (and possibly $\mathrm{CO}_{2}$ inclusions as well) correspond to conditions of the second stage of replacement and origin of magnesite. Data for the low salinity aqueous fluid probably corresponds to the stage three of replacement (M2 process), as this type of fluids was captured exclusively in dolomite 2 and in secondary inclusions in magnesite. Also the $\mathrm{CO}_{2}$ fluid can be alternatively linked to this stage.

Interestingly, previous study of fluid inclusions on some other magnesite deposits (Burda, Ochtiná, Lubeník, Ploské - Huraiová et al., 2002) did not determine any brine inclusions, but only low temperature and low salinity inclusions, similar to our low salinity aqueous inclusions. Perhaps the authors just did not succeeded to find the brines that do not have to always form visible inclusions. Alternatively, the magnesite originated from different type of fluids on the other localities.

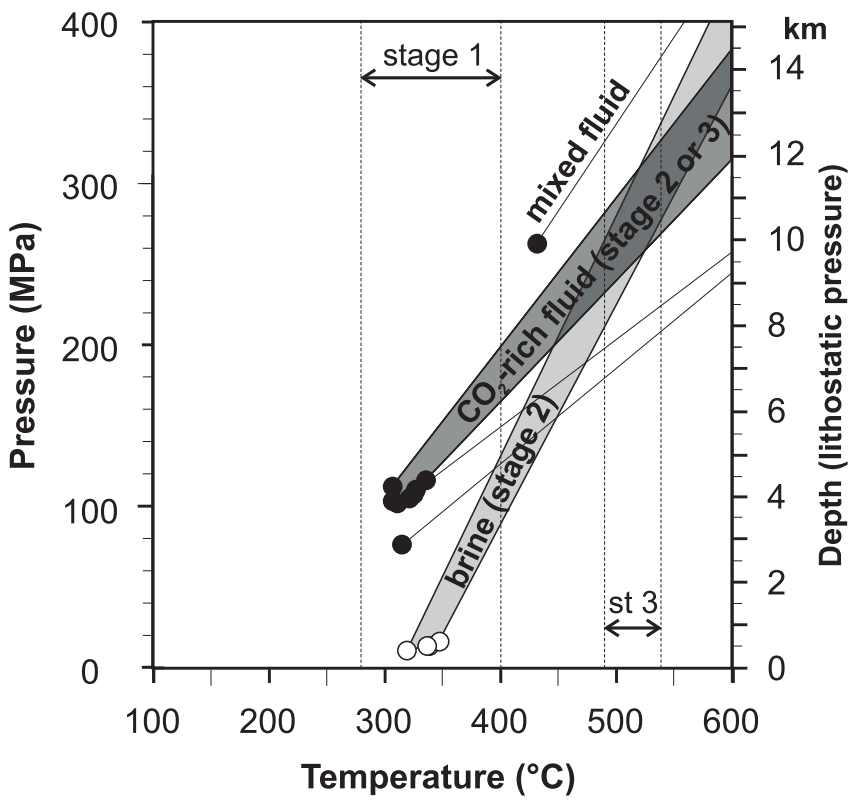

Fig. 14. Isochoric envelopes for inclusions hosted in magnesite from the Hnúšt'a-Mútnik deposit. In addition, temperature ranges for stages one (a part of the M1 process) and three (M2 process), determined from carbonate geothermometry, are also shown (vertical lines). Homogenisation temperatures and corresponding pressures are shown for $\mathrm{CO}_{2}$ rich inclusions (black circles) and brine inclusions (open circles). Two of the $\mathrm{CO}_{2}$ rich inclusion isochores plot significantly outside the main field probably due to the error in estimate of volumetric properties of inclusion phases. PT conditions derived from brines correspond to the stage two of replacement (a part of the $\mathrm{M} 1$ process), while the timing of $\mathrm{CO}_{2}$ rich inclusions is not clear. They can be related to the stage two and/or three. 
KODİ RA, P.; RADVANEC, M. Comparative mineralogical and fluid inclusion study of the Hnúšt'a-Mútnik talc-magnesite and Miková-Jedl'ovec magnesite deposit (Western Carpathians, Slovakia)

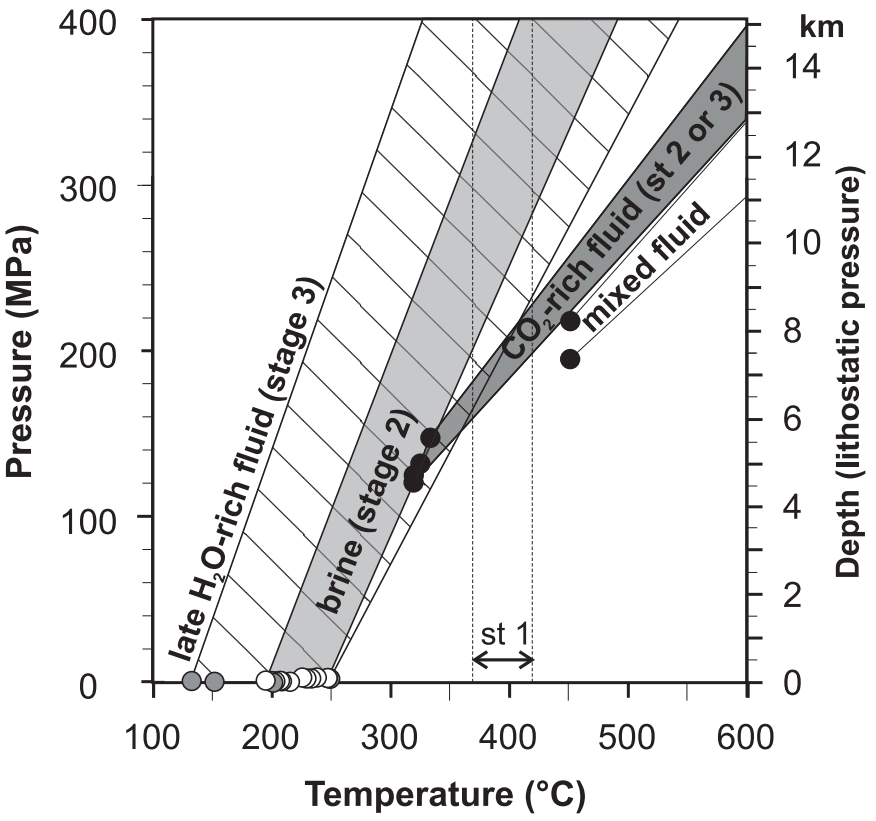

Fig. 15. Isochoric envelopes for inclusions hosted in magnesite and dolomite 2. from the Miková-Jedl'ovec deposit. In addition, temperature range for the stage one (part of the M1 process), determined from carbonate geothermometry, is also shown (vertical lines). Homogenisation temperatures and corresponding pressures are shown for $\mathrm{CO}_{2}$ rich inclusions (black circles), brine inclusions (open circles) and late $\mathrm{H}_{2} \mathrm{O}$-rich inclusions (grey circles). Data for brines correspond to the stage two of replacement (part of the M1 process), while the $\mathrm{H}_{2} \mathrm{O}$-rich inclusions are related exclusively to stage three ( $\mathrm{M} 2$ process). Timing of $\mathrm{CO}_{2}$ rich inclusions is not clear; they can be linked to any of the two stages. Note that uncertainties in salinity calculations of brines may cause some error in the slope of the corresponding isochores. See text for interpretations.

\section{References}

Abonyi, A. \& Abonyiová, M. (1981): Deposit of crystalline magnesite in Slovakia. Mineralia Slov., Monograph., 11-125.

Angus S., Armstrong B., Dereuck K. M., Altunin, V.V., Gadetskii, O.G., Chapela, G.A. \& Rowlinson, J.S. (1976): International thermodynamic tables of the fluid state. Oxford, Pergamon Press, v. 3, 385 p.

Bezák V. ed. (1999). Explanations to geological map of the Slovak ore-mountains - western part. Geological Survey of Slovak Republic. Dionýz Štúr publishers, Bratislava, 1-176. (In Slovak with English resume)

Bodnar, R.J. (1993): Revised equation and table for determing the freezing point depression of $\mathrm{H}_{2} \mathrm{O}-\mathrm{NaCl}$ solutions. Geochim. Cosmochim. Acta, 57, 683-684.

Bowers, T.S. \& Helgeson, H.V. (1983): Calculation of the thermodynamic and geochemical consequences of nonideal mixing in the system $\mathrm{H}_{2} \mathrm{O}-\mathrm{CO}_{2}-\mathrm{NaCl}$ on phase relations in geological systems: Equation of state for $\mathrm{H}_{2} \mathrm{O}-\mathrm{CO}_{2}-\mathrm{NaCl}$ fluids at high pressures and temperatures. Geochim. Cosmochim. Acta, 47, 1247-1275.

Brown, P.E. (1989): FLINCOR: A microcomputer program for the reduction and investigation of fluid-inclusion data. Amer. Mineral., 74, 1390-1393.

Darling, R.S. (1991): An extended equation to calculate $\mathrm{NaCl}$ contents from final clathrate melting temperatures in $\mathrm{H}_{2} \mathrm{O}$ $\mathrm{CO}_{2}-\mathrm{NaCl}$ fluid inclusions: Implications for P-T isochore location. Geochim. Cosmochim. Acta, 55, 3869-3871.

Eggert, R. G., \& Kerrick, D. M. (1981): Metamorphic equilibria in the siliceous dolomite system: 6 kbar experimental data and geological significance. Geochim Cosmochim. Acta, 45, 1039-1047.

Eliáš, K. (1974): Paleotermometrický výskum magnezitových ložísk Západných Karpát. Manuscript - Geol Surv Slovak Rep., Bratislava, 88 p.

Eliáš, K. (1979): Contribution to elucidating formation conditions magnesite deposits by thermometric research. Záp. Karpaty, Sér. Mineral. Petrogr. Geochem. Metalogen. 6, 7-32.

Goldstein, R.H. \& Reynolds, T.J. (1994): Systematics of fluid inclusions in diagenetic minerals. Society for Sedimentary Geology Short Course, 31.

Grecula et al. (1995): Mineral deposits of the Slovak Ore Mountains. Geocomplex, Bratislava, 593-627.

Grecula, P., Radvanec, M., Németh, Z. (2000): Magnesite and talc mineralization in Slovakia. Mineralia Slov., 32, 533-542.

Haynes, F.M. (1985): Determination of fluid inclusion compositions by sequential freezing. Econ. Geol., 82, 14361439. 
KODÌ RA, P.; RADVANEC, M. Comparative mineralogical and fluid inclusion study of the Hnúšt'a-Mútnik talc-magnesite and Miková-Jedl'ovec magnesite deposit (Western Carpathians, Slovakia)

Huraiová, M., Vozárová, A. \& Repčok, I. (2002): Fluid inclusion and stable isotope constraints on the origin of magnesite at Burda, Ochtiná, Lubeník and Ploské deposits (Slovakia, Western Carpathians). Geologica Carpathica, 53, 98-99.

Parry, W.T. (1986): Estimation of $\mathrm{X}_{\mathrm{CO} 2}, \mathrm{P}$ and fluid inclusion volume from fluid inclusion temperature measurements in the system NaCl-CO $-\mathrm{H}_{2} \mathrm{O}$. Economic Geology, 81, 10091013.

Powell, R. J., Condliffe, D. M. and Condliffe, E. (1984): Calcitedolomite geothermometry in the system $\mathrm{CaCO}_{3}-\mathrm{MgCO}_{3}-$ $\mathrm{FeCO}_{3}$ : an experimental study. J. Metamorphic Geology, 2, 33-41.

Prochaska, W. (2000): Magnesite and talc deposits in Austria. Minerlia Slovaca, 32, 543-548.

Prochaska, W. (2001): Magnesite mineralization of the Eastern Alps and the Carpathians. in Piestrzynski et al. eds.: Mineral deposits at the beginning of the $21^{\text {st }}$ century. Proceedings of the $6^{\text {th }}$ SGA Symp., Balkema, Swets \& Zeitlinger Publishers Liss, 1017-1019.

Puhan, D. (1978): Experimental study of the reaction: dolomite $+\mathrm{K}$-feldspar $+\mathrm{H}_{2} \mathrm{O}=$ phlogopite + calcite $+\mathrm{CO}_{2}$ at the total gas pressure of 4000 to 6000 bars. Newes Jahrb. Min., Mh., 110-127.

Radvanec, M. \& Prochaska, W. (2001): Successive replacement of Upper Carboniferous calcite to dolomite and magnesite in Dúbrava magnesite deposit (Western Carpathians, Slovakia). Mineralia Slovaca, 33, 517-525.
Ramboz, C., Pichavant, M., Weisbrod, A. (1982): Fluid immiscibility in natural processes: use and misuse of fluid inclusion data. II. Interpretation of fluid inclusion data in terms of immiscibility. Chem. Geol., 37, 29-48.

Roedder, E. (1984): Fluid inclusions. Mineral. Soc. Amer. Rev. Mineral., 12, 644 p.

Shepherd, T. J., Rankin, A. H., Alderton, D. H. M. (1985): A practical guide to fluid inclusion studies. London, Blackie and Son, $235 \mathrm{p}$.

Schiffries, C.M. (1990): Liquid-absent aqueous fluid inclusions and phase equilibria in the system $\mathrm{CaCl}_{2}-\mathrm{NaCl}_{-} \mathrm{H}_{2} \mathrm{O}$. Geochim. Cosmochim. Acta, 54, 611-619.

Schimmel, F. (1928): Löslichkeiten und unwandlungspunkten der Eisenchlorürhydrate in wäßriger lösung. Zeitschr. Anorg. Chemie, 176, 285-288.

Spencer, R.J., Moller, N., Weare J.H. (1990): The prediction of mineral solubilities in natural waters. A chemical equilibrium model for the $\mathrm{Na}-\mathrm{K}-\mathrm{Ca}-\mathrm{Mg}-\mathrm{Cl}-\mathrm{SO}_{4}-\mathrm{H}_{2} \mathrm{O}$ system at temperatures below $25^{\circ} \mathrm{C}$. Geochim. Cosmochim. Acta, 54, 575-590.

Sterner, S.M, Hall, D.L., Bodnar, R.J. (1988): Synthetic fluid inclusions. V. Solubility relations in the system NaCl-KCl$\mathrm{H}_{2} \mathrm{O}$ under vapor-saturated conditions. Geochim. Cosmochim. Acta, 52, 989-1006.

Zhang, Y.G. \& Frantz, J.D. (1987): Determination of the homogenization temperatures and densities of supercritical fluids in the system $\mathrm{NaCl}-\mathrm{KCl}-\mathrm{CaCl}_{2}-\mathrm{H}_{2} \mathrm{O}$ using synthetic fluid inclusions. Chemical Geology, 64, 335-350. 